\title{
Evolution of Migmatitic Granulite Complexes: Implications from Lapland Granulite Belt, Part II: Isotopic dating
}

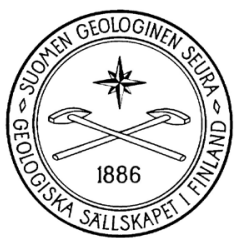

\author{
Pekka Tuisku ${ }^{1) *}$ and Hannu Huhma ${ }^{2)}$ \\ ${ }^{1)}$ Department of Geosciences, University of Oulu, P.O. Box 3000, FI-90014 University of Oulu, \\ Finland \\ ${ }^{2)}$ Geological Survey of Finland, P.O. Box 96, FI-02151 Espoo, Finland
}

\begin{abstract}
The migmatitic metapelites of the Lapland granulite belt (LGB) in the NE part of the Fennoscandian Shield represent an arc-related greywacke basin metamorphosed in the granulite facies. Detrital zircons from migmatitic metapelites are derived from 1.94-2.9 Ga old acid source rocks (U-Pb SIMS ages). The clustering of detrital zircon ages between 1.97 and 2.2 Ga is problematic, because abundant felsic crust of this age is absent in the shield. The metasediments are characterized by Sm-Nd model ages of ca. $2.3 \mathrm{Ga}$. A younger, 1905 I 880 Ma population of homogeneous zircons was formed during regional metamorphism. The peak high-grade metamorphism took place at $\sim 1900 \mathrm{Ma}$ and the latest chronological record from subsequent decompression and cooling phase is from ca. $1870 \mathrm{Ma}$.

The norite-enderbite series of the LGB represents arc-magmas, which were intruded into the metasediments at $\sim 1920-1905 \mathrm{Ma}$ ago according to zircon U-Pb ages and were probably an important heat source for metamorphism. Older, zoned zircon grains in a quartz norite vein, initial $\varepsilon_{\mathrm{Nd}}$ values of 0 to + I and the continuous spectrum of LILE enrichment in the enderbite-series probably reflect assimilation of metasediments by magmas. Monazite U-Pb ages of migmatitic metasediments in the range $1906-1910 \pm 3 \mathrm{Ma}$ overlap the late stage of enderbite intrusion and growth of early metamorphic zircons. Garnetwhole rock $\mathrm{Sm}-\mathrm{Nd}$ ages from leucosomes in the range 1880 - $1886 \pm 7 \mathrm{Ma}$ are concurrent with the growth of the youngest metamorphic zircons and probably indicate the crystallization of leucosomes or the influence of a fluid liberated from them. Isotopic and petrologic data reveal that the evolution of Lapland Granulite belt from the erosion of source rocks to the generation of a sedimentary basin, its burial, metamorphism and exhumation took place within ca. $60 \mathrm{Ma}$.
\end{abstract}

Key words: granulites, Lapland Granulite Belt, metapelite, enderbite, norite, genesis, tectonis, absolute age, U/Pb, Sm/Nd, Paleoproterozoic, Inari, Lapland Province, Finland

*Corresponding author: e-mail: pekka.tuisku@oulu.fi 


\section{Introduction}

The Palaeoproterozoic Lapland granulite belt (LGB) forms an extensive, middle to lower crustal, granulite-facies sequence in the NE Fennoscandian Shield (Eskola, 1952; Meriläinen, 1976; Korja et al., 1996). Its petrology has been a subject of many studies during the last 50 years (Eskola, 1952; Meriläinen, 1976; Hörman et al., 1980; Raith \& Raase, 1986; Barbey \& Raith, 1990; Korja et al., 1996; Leibinger, 1996; Perchuck et al., 2000) and has been recently revised by Tuisku et al. (2006) who demonstrated a regional scale, clockwise PT evolution. Isotopic dating has confirmed that the LGB is Palaeoproterozoic in age (Meriläinen, 1976; Bernard-Griffiths et al., 1984; Huhma \& Meriläinen, 1991; Bibikova et al., 1993; Sorjonen-Ward et al., 1994; Tuisku \& Huhma, 1998, 1999; Daly et al., 2001) and geochemical data suggest that the igneous rocks of the belt were formed in arc setting (Barbey et al., 1986; Bibikova et al., 1993). Tectonically the LGB is thought to represent a crustal scale, SW-directed thrust sequence (Marker, 1988; Korja et al., 1996). Tuisku and Makkonen (1999) found eclogite facies rocks in the SW marginal zone of the LGB suggesting that this could represent part of the NE-subducted slab. Hoffman (1989), Bridgwater et al. (1990) and Hall et al. (1995) have proposed a palaeogeographic correlation of the LGB with the Nagssugtoqidian orogen of Greenland and -1.9 Ga orogenic belts of Baffin Island and Labrador in the Canadian Shield.

The aim of this study was to connect the petrologic and tectonic evolution of the migmatitic metapelites of the LGB and their isotopic ages using SIMS U-Pb zircon dating and other radiogenic isotope methods (Tuisku et al., 2006). U-Pb zircon geochronology of high-grade, partly melted rocks may give a wealth of information on their evolution, because zircon may partly inherit the old crystallization history and may partly be overgrown or recrystallized during younger high-temperature events (Pidgeon \& Aftalion, 1972). Leaching by fluids or some other mechanisms may, however, lead to resetting of isotope systematics (Pidgeon et al., 1966; Sinha et al., 1992). Such reset- ting can make the application of ID-TIMS zircon U$\mathrm{Pb}$ dating methods problematic because meaningless mixed ages may be obtained (Metzger \& Krogstad, 1997). By the use of secondary ion mass spectrometry (SIMS) the problem may often be resolved, because isotope ratios can be measured separately in different zones of zircon grown or annealed during distinct episodes (Williams, 1992). Consequently, SIMS dating of zircon has been used successfully in areas with complicated, high-temperature (HT) geological histories. These include the resolving HT history of migmatite, gneiss or igneous sequences (Oliver et al., 1999; Vanderhaeghe et al., 1999; Nutman et al., 1999; White et al., 1999), determining the rate of orogenic events (Bodorkos et al., 2000), the source of granitic rocks (Keay et al., 1999) and the provenance of metasedimentary sequences (Murphy \& Hamilton, 2000; Sircombe, 2000). Also, dating of lower T retrogression and fluid flow in metamorphic belts has been successful (Williams et al., 1996). SIMS data are especially useful when the dating is combined with morphological analysis of zircon grains using cathodoluminescence (CL) and/or backscattered electron imaging (BEI) (Vavra et al., 1999).

In many cases, conventional $\mathrm{U}-\mathrm{Pb}$ or other dating methods ( $\mathrm{Pb}-\mathrm{Pb}, \mathrm{Sm}-\mathrm{Nd}$ ) may also give important information on the evolution of high-grade metamorphic belts, either used alone or combined with the SIMS method (Buick et al, 1999; Chen et al., 2000). Recently, especially monazite data have proven useful in determining metamorphic and/or deformation phases (Bruguier et al., 1999; Crowley \& Parrish, 1999, Foster et al., 2000), thermal history of metamorphic complexes (Aleinikoff et al., 2000; Hawkins \& Bowring, 1999) or their geodynamic regime (Vavra \& Schaltegger, 1999). One reason for the increased utility of monazite in geochronology of high-grade rocks is that monazite is apparently not reset and annealed as easily as earlier thought and may resist fluids even more efficiently than zircon (Parrish \& Whitehouse, 1999; Schaltegger et al., 1999; Vavra $\&$ Schaltegger, 1999). 
Our second objective is to clarify the possible connection between the geotectonic evolution in the NE part of the Fennoscandian Shield, including the LGB, and the Svecofennian arc domain, now exposed in the central and SW part of the Shield, as well as clarify the nature of the proposed models invoking divergent to convergent, ca. 2.0 - 1.8 Ga plate tectonic processes in the Fennoscandian Shield (Gaál \& Gorbatschev, 1987; Korsman et al., 1997). Last, it is extremely important to get precise provenance, deposition and metamorphic evolution data on the LGB for Proterozoic palaeogeography and correlation of the 1.8 - 2.0 Ga orogenic belts (Gaál \& Gorbatschev, 1987; Hoffman, 1989; Bridgwater et al., 1990; Hall et al., 1995)

\section{Geological setting}

The geological setting of the LGB is described in more detail in the first part of this paper (Tuisku et al., 2006). The LGB consists of metasedimentary granulites, ranging in composition from psammitic to pelitic and, noritic to enderbitic igneous rocks. Both rock series are tectonized and are usually dipping gently to NE, except at the northeastern margin, where the dips are steeply south-westwards. Anorthosites are found as one major unit and some smaller concordant sheets. According to available geochronological evidence, most of the metapelitic, enderbitic and anorthositic rocks have an age range from about 2.0 to 1.9 Ga (Meriläinen, 1976; Bernard-Griffiths et al., 1984; Huhma \& Meriläinen, 1991; Sorjonen-Ward et al., 1994; Daly et al., 2001).

The NE and SW sides of the LGB are bordered by tectonized zones and thrusts (Marker, 1988; Korja et al., 1996). The SW marginal series contains a tectonic mixture of highly strained, banded, rocks which were metamorphosed in relatively high-pressure of 12 kbar. This, together with the intensive transposition during the thrusting of the LGB, suggests that the areas to the SW were included in the subducting slab and formed a foreland area (Tuisku \& Makkonen, 1999). Yet the areas to the SW contain Archaean gneiss complexes $(3.1-2.6 \mathrm{Ga})$ and Palaeoproter- ozoic, greenstone-dominated supracrustal sequences (ca. $2.3-2.0 \mathrm{Ga}$ ), which were folded before thrusting of the LGB to the SW (Kröner et al., 1981; Korja et al., 1996; Braathen \& Davidsen, 2000; Vaasjoki, 2001). In the NE, the LGB is bordered by a gneiss complex, called the Inari Terrane, which is dominantly composed of Neoarchaean basement but also contains Palaeoproterozoic plutons having an age of 1.95 - 1.9 Ga (Meriläinen, 1976; Kesola, 1995; Korsman et al., 1997). Younger ca. 1.77 - 1.88 Ga granitic plutons intrude discordantly both the LGB and the complexes to the southwest and northeast of it (Meriläinen, 1976; Huhma, 1986; Korsman et al., 1997).

\section{Samples}

Profile mapping was carried on throughout the exposed section of the LGB. Two outcrops of migmatitic metapelite were selected for isotopic work with the SIMS. Different fractions, leucosomes, melanosomes and mesosomes were collected separately in the field and the work was later completed with the use of diamond saw in the laboratory. In the other locality, a narrow quartz norite vein was sampled. Also, three enderbite bodies were sampled for conventional zircon U-Pb dating.

\section{I. Migmatitic metapelites}

Two migmatite outcrops were sampled for dating. The first, I1 (Fig. 1) is from Kuttura Village, near the southwestern margin of the LGB and represents the lowermost structural unit of the belt just below the first appearance of enderbite bodies in the second unit (Korja et al., 1996). The other, I5 (Fig. 1) is from the vicinity of Kaarle Kustaa gold mining shaft, ten kilometres south of the Saariselkä village and represents the third structural unit of the belt. A quartz norite vein of the enderbite-norite series was also sampled from the same outcrop (Fig.1).

The Kuttura outcrop (I1) is a more than $1 \mathrm{~km}$ long section in the Ivalojoki canyon. The rocks collected here were earlier used for carbon isotope and elastic studies (Korja et al., 1996; Seipold et al., 1998). 


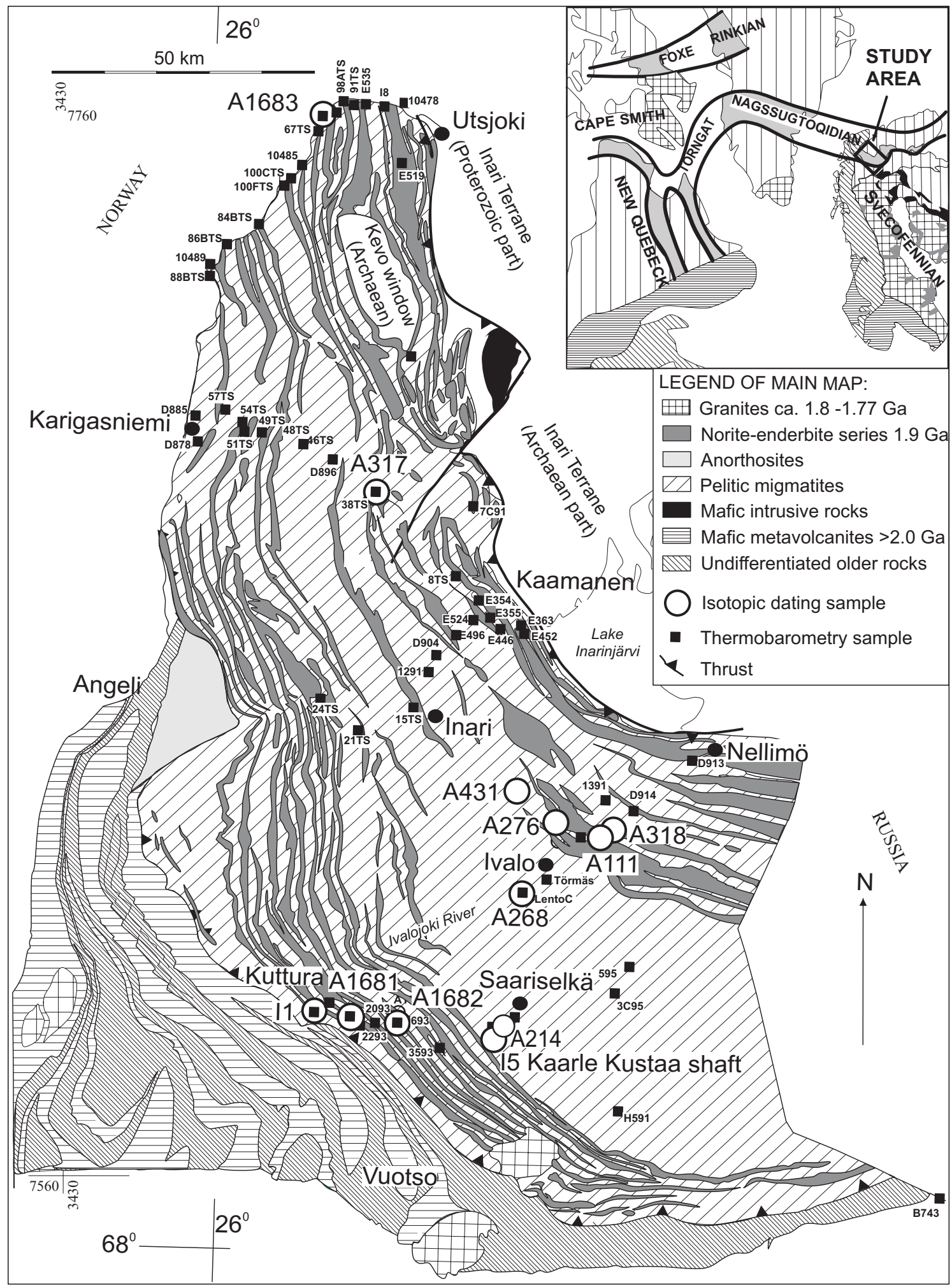

Fig. I. Geological map of the Lapland Granulite Belt in Finnish territory. The map shows major lithological subdivision of the LGB and location of samples used for isotopic dating. The inset shows the location of the study area in the Fennoscandian shield and correlation in the North Atlantic Realm proposed by Hoffman (1988). Black areas in the inset are Karelian metasediments and grey areas in the checked area of the inset are Svecofennian metasediments. 
The rock is partly banded, blastomylonite and partly schlieren migmatite with well-developed neosomes. This rock also has exceptionally graphite-rich portions, which were used for carbon isotope measurements (Korja et al., 1996). Although the banded type prevails in the outcrop, the schlieren type was sampled because mesosomes, melanosomes and leucosomes were easier to separate (compare Figs .4 and 6 in Part I, Tuisku et al., 2006)

Sample I1.3 (Nordsim number n273) was separated from foliated mesosomes predominantly consisting of fine-grained oligoclase-quartz matrix with garnet porphyroblasts. Garnet contains inclusions of quartz, sillimanite and rutile and is partially replaced by biotite, sillimanite and plagioclase at the margins. Accessory phases in the matrix are graphite, biotite, sillimanite, rutile, orthoclase, pyrrhotite, chalcopyrite, and zircon. The amount of zircon is relatively large but the grains are small, usually about $10 \mu \mathrm{m}$ and rarely $>100 \mu \mathrm{m}$, zoned and rounded. Some late sericite and chlorite is encountered as alteration products of feldspars and biotite, respectively.

Sample I1.2 (Nordsim number n275) was separated from exceptionally well-developed melanosomes. More than fifty percent of the rock is made of garnet porphyroblasts, which are embedded in an oriented sillimanite-biotite matrix, with lesser amounts of rutile, quartz and locally oligoclase. Garnet contains inclusions of plagioclase, quartz, sillimanite, and rutile. Also, some orthoclase-bearing enclaves with quartz, plagioclase and myrmekite are found, probably representing leucosome material. Accessory phases include graphite, zircon, sulphides, and monazite. Zircon grains are small $(<100 \mu \mathrm{m})$ and rounded. Some are zoned; others are homogeneous or have a zoned core. Monazite grains are optically homogeneous, rounded and usually less than $200 \mu \mathrm{m}$ in diameter.

Sample 11.1 (Nordsim number n274) was taken from a medium- to coarse-grained leucosome. In the outcrop, the leucosome seems to be pegmatitic and massive, but under the microscope a clear foliation is evident. Large orthoclase grains, up to $3 \mathrm{~cm}$ in diameter, are partly granulated to fine granoblastic domains giving the rock a mortar texture. Quartz domains up to $3 \mathrm{~cm}$ long are elongated, granulated and quartz has sutured margins and chessboard extinction. Also oligoclase occurs as large granoblastic domains having some larger relics. Both types of feldspar have a regular crystal orientation within their domains suggesting that the texture was produced by granulation of larger grains. Sub-idiomorphic garnet grains are $1-$ $4 \mathrm{~mm}$ in diameter, contain a few inclusions of quartz and are partly replaced by biotite. Neither monazite nor apatite inclusions were found in garnet. Aggregates of small sillimanite prisms occur sporadically within granulated feldspars. Andalusite occurs as anhedral to subhedral grains, ca. $0.5-1 \mathrm{~mm}$ in diameter and has sometimes a micropegmatitic rim of feldspar and quartz. Relatively large, optically homogeneous monazite grains, up to $0.5 \mathrm{~mm}$ in diameter, are grown at the margin of leucosome and melanosome. Other accessory phases include graphite and zircon. Zircon grains are usually less than $100 \mu \mathrm{m}$ in diameter, may have a zoned core with a discordance of zoning to the outer margin, and usually have an optically homogeneous rim. Homogeneous round-shaped zircons are also common.

The Kaarle Kustaa sampling site (I5) consists of a small, $>10 \mathrm{~m}$ wide quarry near an old gold mining shaft with some separate, glacially eroded bedrock surfaces nearby. The rock consists of a blastomylonitic, strongly parallel-banded mesosome-leucosome mixture with sparse, mm-wide darker melanosome bands, which occur either at the margins of mesosomes or separately in leucosomes. Ten to fifty centimeter thick layers of massive-looking, yellowish leucosomes occur concordantly with the banded rock, as does the quartz norite vein described above.

Sample I5.2 (Nordsim number n277) was taken from the banded, heterogeneous part of the rock, which contains both leuco-, meso- and melanosome fractions. In the laboratory, the final sampling was done to concentrate the meso- and melanosome part for zircon separation, but because of the finely banded structure the leucosome parts could not be avoided totally. Thus the sample is a concentrate of both the meso- and melanosome but may also contain small fraction of leucosome. The mesosome consists 
of a fine-grained, granoblastic plagioclase-quartz matrix with abundant garnet porphyroblasts and a lesser amount of biotite. Garnet contains inclusions of biotite and quartz. Accessory phases include rutile, small amounts of interstitial orthoclase, sporadic sillimanite and small, zoned and abraded zircons. The melanosomes show variation but are usually enriched in garnet, biotite, sillimanite, and rutile relative to plagioclase and quartz. One type also contains pyrrhotite and chalcopyrite while the other contains spinel. In the latter, spinel is found only as inclusions in garnet and sillimanite while garnet is in turn replaced by biotite-quartz-sillimanite symplectite at the rims. Rounded zircon grains are relatively common. They are usually less than $50 \mu \mathrm{m}$ in diameter, and homogeneous, but also some zoned larger grains were found.

Sample I5.1 (Nordsim number n283) is from a homogeneous, $50 \mathrm{~cm}$ wide leucosome. Macroscopically, the rock looks massive but is revealed to be lineated by rodded quartz. The leucosome consists of extremely stretched quartz rods and a fine-grained plagioclase $\left(A n_{30}\right)$ - orthoclase matrix, which has a granoblastic or aplitic texture. Flattened, larger porphyroclasts of orthoclase are granulated at the ends and embayed by myrmekite from the flat sides. Round or flattened garnet gains are abundant, three to ten millimetres in diameter and contain a few inclusions of quartz, biotite, rutile, zircon, pyrrhotite, chalcopyrite and ilmenohaematite. Monazite was not encountered as inclusions in garnet. Accessory phases in the matrix are rutile, pyrrhotite, chalcopyrite, pyrite, and zircon, which occurs as small, round-shaped grains $(<100 \mu \mathrm{m})$, is usually zoned in the core, and has a wide homogeneous rim.

\subsection{Norites and enderbites}

Four norite-enderbite series outcrops were selected for dating. Sample I5.3 (Nordsim number n276) was taken from a narrow, $10 \mathrm{~cm}$ wide and conformable quartz norite vein in a migmatitic metapelite near the Kaarle-Kustaa shaft, where metapelites were also sampled for dating (Fig. 1). The vein has knife-sharp contacts and does not show the shearing seen in the sur- rounding metapelite. The quartz norite is grey, relatively fine-grained $(0.5 \mathrm{~mm})$ and foliated. Labradorite $\left(\mathrm{An}_{56}\right)$ makes up about $60 \%$ of the rock. Finegrained hypersthene, biotite and quartz are other major minerals while accessory phases include apatite, zircon, pyrrhotite, and chalcopyrite.

Two samples (A1681 and A1682) were taken from the second structural unit of the LGB (Korja et al., 1996). Sample A1681 is from a ca. $200 \mathrm{~m}$ thick, conformable quartz-hypersthene diorite sill, which is the second of eleven large intrusions in this unit. The rock is strongly lineated, relatively fine-grained, gneissic and consists of ca. $80 \%$ of andesine $\left(\mathrm{An}_{40}\right)$, $10 \%$ of hypersthene and $5 \%$ of rodded quartz, and accessory biotite, ilmenohaematite, magnetite, apatite, antiperthite, and euhedral zircon. Sample A1682 is from a ca. $500 \mathrm{~m}$ thick enderbite sill, being the fifth of the large intrusions of the second unit. The rock varies from slightly to considerably lineated, is medium-grained, and consists of $70 \%$ of andesine $\left(\mathrm{An}_{35}\right)$, $10 \%$ of oriented hypersthene and $15 \%$ of quartz. Accessory phases include biotite, ilmenohaematite, magnetite, apatite, orthoclase, and euhedral zircon. In the footwall the sill changes to a garnet- and biotite-bearing contact variety.

Sample A1683 was taken from a $100 \mathrm{~m}$ thick footwall satellite of about $600 \mathrm{~m}$ thick enderbite intrusion in the fourth structural unit (Korja et al., 1996). The rock is lineated, medium-grained, and consists of $75 \%$ andesine $\left(\mathrm{An}_{44}\right)$ with abundant antiperthite exsolutions, some quartz and hypersthene and accessory biotite, clinopyroxene, apatite, anhedral zircon, and ilmenohaematite, magnetite and pyrrhotite. In the footwall the rock changes to norite, banded norite/ enderbite and finally to a garnet-bearing contact variety adjacent to the migmatitic metapelite.

\section{Methods}

After crushing to approximately $200 \mu \mathrm{m}$, zircon, monazite and garnet separates were prepared from each sample using magnetic and heavy liquid separation. The work was completed by hand picking.

Different morphological and variably coloured 
types of zircons were selected from each SIMS-sample by handpicking. Their internal structure and morphology were studied by SEM-BSE imaging using JEOL JSM-6400 scanning electron microscope. Approximately 400 grains were studied. U-Th-Pb analyses of zircons were performed using the Cameca IMS1270 ion-microprobe at the Swedish Museum of Natural History, Stockholm (NORDSIM facility). The analytical procedure is described in Whitehouse et al. (1997, 1999). The geostandard used was zircon 91500 having an age of $1065.4 \pm 0.3 \mathrm{Ma}$ (Wiedenbeck et al., 1995). Oxygen flooding in the sample chamber was used to improve the sensitivity of $\mathrm{Pb}$. Data reduction was performed by the Nordsim software written by M.J. Whitehouse. A total of 68 zircon analysis points were measured from six rock fractions and two geographic positions.

Relatively large, transparent, yellow monazite grains were selected for conventional U-Pb analyses. The methods for zircon and monazite follow the procedures by Krogh (1973). Crystals were washed in dilute $\mathrm{HCl}$ in ultrasonic bath and dissolved in $\mathrm{HF}$ and $\mathrm{HNO}_{3}$ at $200{ }^{\circ} \mathrm{C}$ for a few days in Teflon capsules inside larger Teflon pressure vessels with a stainlesssteel jacket. After evaporation of fluorides the sample in $\mathrm{HCl}$ solution was aliquoted and a mixed ${ }^{206} \mathrm{~Pb} /$ ${ }^{235} \mathrm{U}$ (for monazite) or ${ }^{208} \mathrm{~Pb} /{ }^{235} \mathrm{U}$ (for zircon) isotopic tracer was added. For isotopic measurements $\mathrm{Pb}$ was loaded on single Re filament with Si-gel and $\mathrm{H}_{3} \mathrm{PO}_{4}$, and $\mathrm{U}$ on Ta-side filament of a triple filament assembly using $\mathrm{H}_{3} \mathrm{PO}_{4}$. Measurements were made using a VG Sector 54 mass spectrometer. The performance of the ion counter was checked by repeated measurements of the NBS 983 standard. Programs by Ludwig $(1991,2001)$ have been used for age calculations.

Garnet separates were further purified by handpicking and were followed by stepwise dissolution method of DeWolf et al. (1996) involving crushing of garnet in a boron carbide mortar and leaching in 6 $\mathrm{M} \mathrm{HCl}$. Samples were dissolved in $\mathrm{HF}-\mathrm{HNO}_{3}$ using Savillex screw-cap teflon beakers (for garnet, $200 \mathrm{mg}$ ) and teflon bombs (for whole rocks, $150 \mathrm{mg}$ ) for 48 h. After careful evaporation of fluorides with $\mathrm{HClO}_{4}$ and $\mathrm{HNO}_{3}$ the residue was dissolved in $6 \mathrm{M} \mathrm{HCl}$ and a clear solution was achieved. A mixed ${ }^{149} \mathrm{Sm}^{150} \mathrm{Nd}$ spike was added to the sample prior to the dissolution. Measurements were made in a dynamic mode on a VG Sector 54 mass spectrometer using triple filaments. Based on duplicate analyses, the estimated error in ${ }^{147} \mathrm{Sm} /{ }^{144} \mathrm{Nd}$ is $0.3-\%(2 \sigma) .{ }^{143} \mathrm{Nd} /{ }^{144} \mathrm{Nd}$ ratio is normalized to ${ }^{146} \mathrm{Nd} /{ }^{144} \mathrm{Nd}=0.7219$. The average value for La Jolla standard was ${ }^{143} \mathrm{Nd} /{ }^{144} \mathrm{Nd}=0.511852$ \pm 12 (standard deviation of 23 measurements, errors in last significant digits). The blanks measured during analyses were $30 \mathrm{pg}$ for $\mathrm{Sm}, 100 \mathrm{pg}$ for $\mathrm{Nd}$ and $30 \mathrm{pg}$ for $\mathrm{Pb}$.

\section{Description of zircon}

\section{I. Migmatites}

Zircon grains with different morphology, internal structure, zoning, inclusion pattern and colour were distinguished in the SIMS-samples. Each sample has distinct zircon population but there are also similarities between the samples. Back-scattered electron images were used for characterization of the zircons.

Three major and two minor types of zircon grains are found. The first shows distinct concentric oscillatory zones, sometimes interrupted by igneous resorption discordances. It often contains small inclusions, and is similar to zircons typically found in silicic igneous rocks (see e.g. Söllner et al., 1997). The grains have always abraded margins, which are revealed by discordance in crystal facets and a rounded or wellrounded form of the grains (Fig. 2a-i). On a textural basis, these grains are considered detrital.

The second type is otherwise similar to the first one, but a homogeneous rim surrounds the zoned part and is often separated from the core by tiny inclusions or a narrow crack. The external shape of these grains is roundish, sub-spherical or oval (Fig. $2 \mathrm{k}-\mathrm{p})$. The homogeneous parts are interpreted to be metamorphic overgrowths on detrital grains. Apparently no replacement of the detrital core has usually taken place, because the chain of inclusions is common between the two parts, the form of the cores is similar to that of detrital grains and no embayments of homogeneous material penetrate into the zoned 
part. A tiny embayment of homogeneous zircon into a zoned core was only observed along a crack in some of the grains (e.g. Fig. 2n, top of the grain).

The third major type consists of homogeneous grains, mostly with a roundish but sometimes embayed external form (Fig. 2r-t). This type may show faint sector zoning, generally lacks inclusions and is usually much brighter in the BSE than the first type, indicating higher heavy element concentrations.
The first of the minor types has an irregular, patchy zoning. Sometimes the lighter parts show relict oscillatory zoning and the grains are interpreted as metamictization products of detrital grains (Fig. 2j). The reason for decomposition of these grains may be an originally high concentration of heavy radioactive elements, because the relict parts are usually much brighter than the "normal" zoned grains. The second minor zircon grain type consists of a homoge-

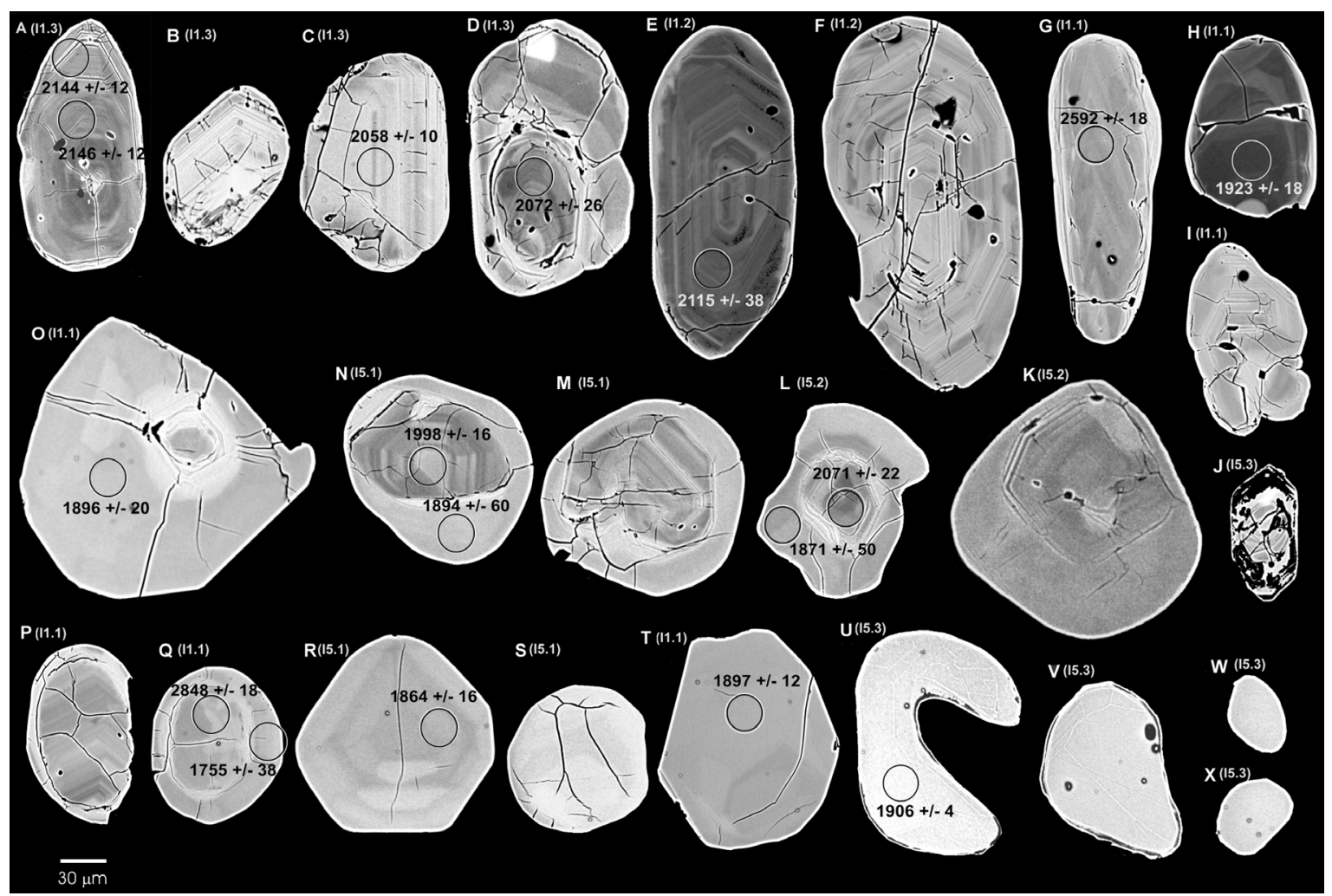

Fig. 2. Backscattered electron (BSE) images of zircon grains form the LGB. The scale and exposure settings are similar to better illustrate the variation in shape, zoning and total heavy element concentration, indicated by brightness of the mineral (scale bar $=30 \mu \mathrm{m}$ ). Grains $\mathbf{A}-\mathbf{I}$ are detrital without metamorphic overgrowths. A - D are from mesosome in Kuttura (sample II.3, Pb-Pb ages: core of A $2146 \pm I 2$ (n273-02a) and tip $2144 \pm I 2$ Ma (n273-02b), C: 2058 $\pm 10 \mathrm{Ma}$ (n273-30) and D: 2072 26 Ma [discordant] (n273-3I)). E and F are from melanosome in Kuttura (sample II.2, Pb-Pb age of $\mathrm{E}$ is $2 \mathrm{II} \pm \pm 38 \mathrm{Ma}$ [discordant] (n275-30)). G-I are from leucosome in Kuttura (sample II.I,

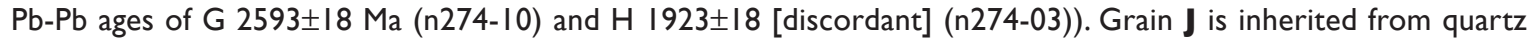
norite in Kaarle Kustaa (samplel5.3). Grains K-Q are detrital with metamorphic overgrowths. $\mathbf{K}$ and $\mathbf{L}$ are from meso-melanosome in Kaarle Kustaa (sample I5.2, Pb-Pb ages of L: core 207I \pm 22 Ma (n277-06b) and rim I87I \pm 50 Ma [high common lead in rim] (n277-06a)). $\mathbf{M}$ and $\mathbf{N}$ are from leucosome in Kaarle Kustaa (sample I5.I, IPb-Pb ages of $\mathrm{N}$ : core 1998 $\pm 32 \mathrm{Ma}(\mathrm{n} 283-\mathrm{I7b})$ and rim $1894 \pm 60 \mathrm{Ma}$ [high common lead in rim] (n283-I7a)). $\mathbf{O}-\mathbf{Q}$ are from leucosome in Kuttura (sample II.I, Pb-Pb ages: rim of O 1896 20 Ma (n274-06), core of Q $2848 \pm 18$ Ma [discordant] (n274-35b) and rim of Q $1755 \pm 38$ Ma [discordant] (n274-35a)). R - T are homogeneous metamorphic grains from leucosomes, without detrital cores. $\mathbf{R}$ and $\mathbf{S}$ are from Kaarle Kustaa (sample I5.I) and $\mathbf{T}$ is from Kut-

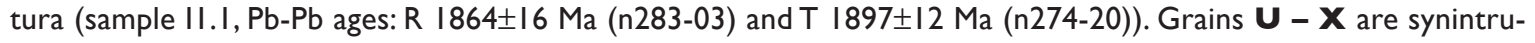
sive grains from quartz norite in Kaarle Kustaa (sample 15.3, Pb-Pb age of U 1906 4 Ma (n276-02)). 
neous core rimmed by a homogeneous part. The core is usually much darker than the rim but in a couple of grains almost as bright as the rim (e.g. Fig. 2q). These cores are also interpreted to be detrital, but their provenance is obviously different from that of the major grain types.

At both sampling sites, Kuttura and Kaarle-Kustaa, the zircon population in metapelites was similar, although the sites represent different structural levels of the LGB. The mesosomes are characterized by zoned detrital zircon without any overgrowths (Fig. 2a-d) or, to a lesser extent, detrital zircon grains with variable overgrowths (Fig. 2k-1). The melanosomes are nearly similar containing purely oscillatory-zoned detrital grains (Fig. 2e-f) or detrital grains with homogeneous overgrowths. The leucosomes are different. Although some of their detrital grains contains no overgrowths (Fig. 2g-I), the majority of the detrital zircons have well-developed homogeneous overgrowths (Fig. 2mq). Also, homogeneous zircons with no zoned cores are abundant in leucosomes (Fig.2r-t).

\subsection{Quartz norite vein}

The zircon population in the quartz norite vein differs from that of any metapelite fraction. About $60 \%$ of the grains are heterogeneous, either clearly oscil- latory-zoned detrital grains or patchy-zoned grains (Fig 2j). The oscillatory-zoned grains may rarely be surrounded by a narrow homogeneous overgrowth. Some grains are exceptionally dark in BSE, rounded and may contain a narrow overgrowth similarly to oscillatory-zoned grains. About $40 \%$ of the zircons are extremely homogeneous and round-shaped, rarely skeletal (Fig. $2 \mathrm{u}-\mathrm{x}$ ), which makes the zircon population in the quartz norite in some respect similar to the zircons from the leucosomes of the metapelites. However, in contrast to the leucosomes, the zoned grains in the quartz norite lack broad overgrowths. The homogeneous grains in the quartz norite are translucent and red-brown in colour contrary to all other zircons, which are colourless and translucent.

\section{Isotopic dating}

\section{I. Zircon U-Pb dating (SIMS)}

The results from the Kuttura sampling site (I1) in Table 1 are grouped according to the above petrographic classification. It is noteworthy that sorting was solely based on the petrographic distinction of the sample type and zircon type. Homogeneous zircons grains were analyzed both from the melanosome (n275) and leucosome (n274) fractions of the migmatite. Most analyses are concordant and provide ${ }^{207} \mathrm{~Pb} / 206 \mathrm{~Pb}$

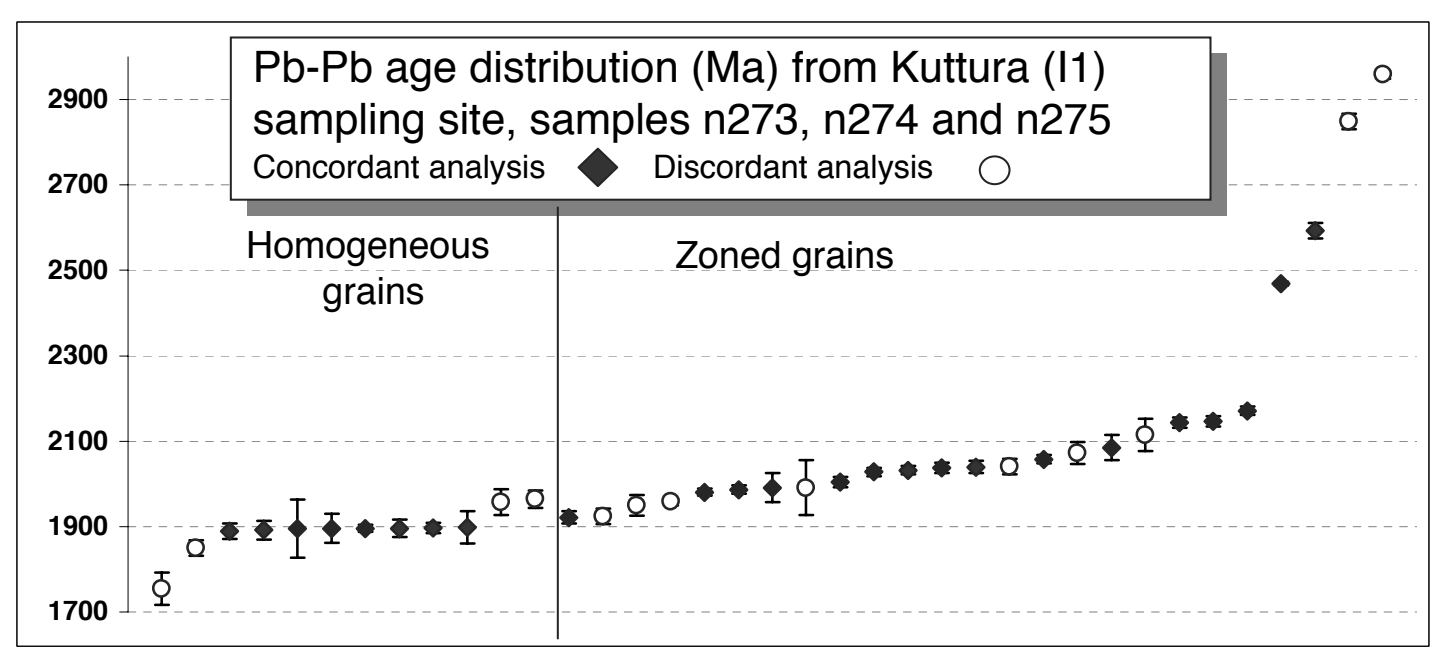

Fig. 3. Distribution of ${ }^{207} \mathrm{~Pb} /{ }^{206} \mathrm{~Pb}$-ages (with $2 \sigma$ error bars) of homogeneous and zoned zircon grains from Kuttura sampling site, II. Black diamonds indicate concordant determinations and white circles discordant. 


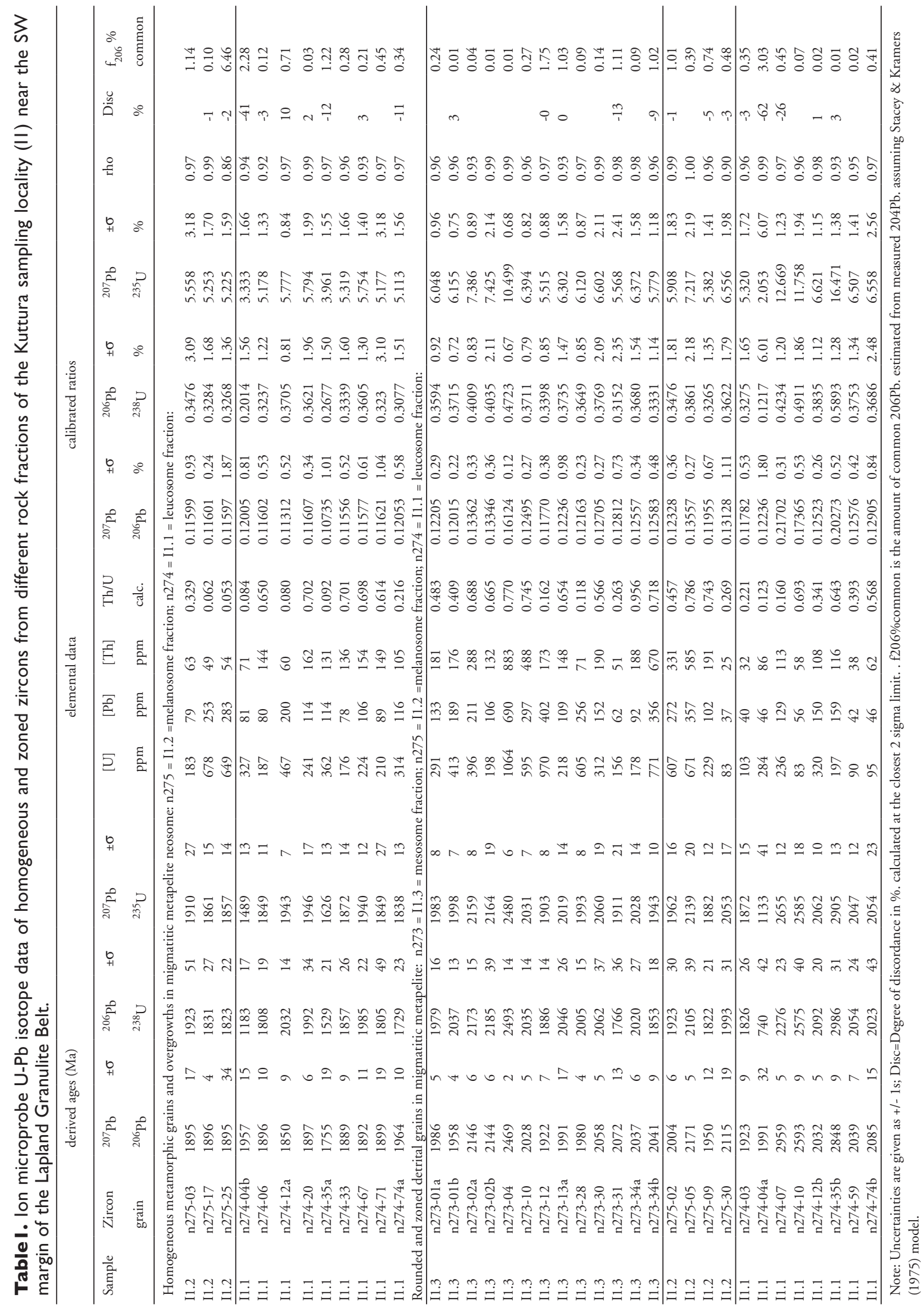


ages between $1889 \pm 18$ and $1899 \pm 38 \mathrm{Ma}(2 \sigma)$, as seen from Table 1 and Fig. 3, where the results are arranged according to the zircon type and then in increasing ${ }^{207} \mathrm{~Pb} /{ }^{206} \mathrm{~Pb}$ age. The heavy diamonds indicate concordant (at $2 \sigma$ level) and the open circles discordant analysis. A weighed average age of $1895 \pm 6$ $\mathrm{Ma}$ can be calculated for eight concordant analyses (Fig. 3).

The zoned grains analyzed from all three migmatite fractions yield an age range from $1922 \pm 14$ to $2593 \pm 18 \mathrm{Ma}(2 \sigma)$, if the ${ }^{207} \mathrm{~Pb} /{ }^{206} \mathrm{~Pb}$ ages of the concordant analysis spots are considered. The majority of the ${ }^{207} \mathrm{~Pb} /{ }^{206} \mathrm{~Pb}$ ages fall between $1980 \pm 8$ and 2171 $\pm 10 \mathrm{Ma}$. Only one concordant grain has a younger age $1922 \pm 14 \mathrm{Ma}$ (n273-12a), and two were dated older at $2469 \pm 4$ and $2593 \pm 18 \mathrm{Ma}$. However, the amount of common lead in analysis $\mathrm{n} 273-12 \mathrm{a}$ is relatively high and so its precise age is sensitive to common $\mathrm{Pb}$ correction.

At the Kaarle Kustaa sampling site (I5) the homogeneous zircons both in the leucosome, melanosome and mesosome give slightly younger to similar ${ }^{207} \mathrm{~Pb} /$ ${ }^{206} \mathrm{~Pb}$ ages as at Kuttura, ranging from $1864 \pm 16$ to $1900 \pm 12 \mathrm{Ma}$ (Table 2, Figs 4 and 5). For clarity, the error ellipses are drawn at $1 \sigma$ level in Fig. 5; at $2 \sigma$ level most of the analyses are concordant. The youngest ${ }^{207} \mathrm{~Pb} /{ }^{206} \mathrm{~Pb}$ ages of the concordant zoned grains at Kaarle Kustaa are $1937 \pm 8 \mathrm{Ma}$ in the leucosome fraction and $1956 \pm 20 \mathrm{Ma}$ in the meso/melanosome fraction. The majority of the ${ }^{207} \mathrm{~Pb} /{ }^{206} \mathrm{~Pb}$ ages fall between $1.96 \mathrm{Ga}$ and $2.1 \mathrm{Ga}$, only one slightly discordant analysis yields an older ${ }^{207} \mathrm{~Pb} /{ }^{206} \mathrm{~Pb}$ age (ca 2.4 $\mathrm{Ga})$. The age distribution of zoned zircon grains is thus similar in both sites (Figs. 3 and 4).

The homogeneous zircons in the quartz norite vein at Kaarle Kustaa (I5.3; n276) have very high Ucontent and provide concordant U-Pb analyses yielding an average ${ }^{207} \mathrm{~Pb} / 206 \mathrm{~Pb}$ age of $1906 \pm 4 \mathrm{Ma}$ (Table 2, Fig. 5). Zoned grains in the quartz norite give older and variable ${ }^{207} \mathrm{~Pb} /{ }^{206} \mathrm{~Pb}$ ages. The youngest of these zircons has the same ${ }^{207} \mathrm{~Pb} /{ }^{206} \mathrm{~Pb}$ age as the youngest zoned grains of the migmatitic metapelites both at this locality and Kuttura have. Two of the grains are concordant at $2041 \pm 10$ and $2114 \pm 24 \mathrm{Ma}$ and thus represent the same age group as the majority of the zoned grains in the metapelites. Two of the grains have an Archaean age.

\subsection{Zircon U-Pb dating (conventional/ID- TIMS)}

Three samples of enderbite-norite series were dated by the conventional multi-grain zircon U-Pb method. Samples I3 (A1681) and I4 (A1682) were taken from the roadside outcrops between Kuttura and Kaarle Kustaa sampling sites. The zircon grains in both samples are euhedral and zoned, as is typical for igneous rocks. Most grains are elongated, pale brown or almost colourless, and clear, with shiny, resorbed surfaces. The two U-Pb analyses of A1681 zircon are nearly concordant and indicate an age of $1919 \pm 3 \mathrm{Ma}$ (Table 3, Fig. 6). The three zircon analyses of A1682 are also nearly concordant, and provide ${ }^{207} \mathrm{~Pb} /{ }^{206} \mathrm{~Pb}$ ages of 1916 - 1921 Ma. More data would be needed for determining the precise magmatic age, but very likely the result is close to $1920 \mathrm{Ma}$.

The third sample, A1683, is from the northern part of the LGB. Zircon grains in this enderbite are rounded, transparent and have shiny surfaces. Some of them contain discernible core and rim in transmitted light. The two U-Pb analyses are slightly discordant and provide ${ }^{207} \mathrm{~Pb} / 206 \mathrm{~Pb}$ ages of ca. $1921 \mathrm{Ma}$ (Table 3, Fig. 6). This result is close to that from the previous samples, but the precise magmatic age remains uncertain. Compared to the quartz norite vein at Kaarle Kustaa (I5.3), the U content in zircon is low in these three enderbites.

In the 1970's a number of U-Pb analyses on zircon were made on LGB. Those from quartz diorites (A111 Akujärvi) provided nearly concordant data, which suggested an age of $1925 \pm 12 \mathrm{Ma}$ (Meriläinen, 1976, Fig 60). Consequently, all zircon data from distant quartz-diorite/enderbite samples suggest an age of ca. $1.92 \mathrm{Ga}$. The ultimate reason for the slight scatter in the data within and between samples remains to be solved by more detailed investigation of zircon internal structures and SIMS analyses. 


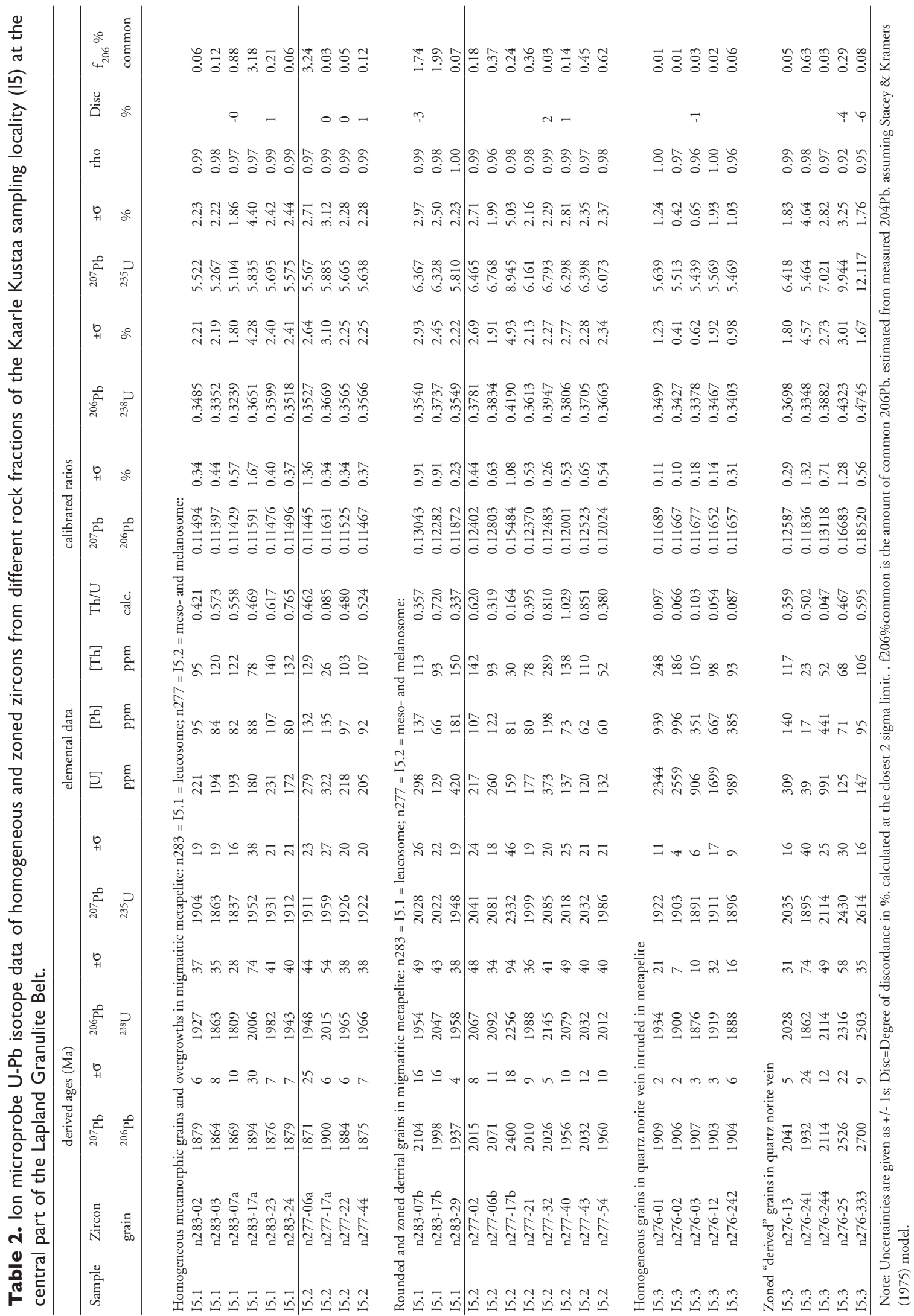




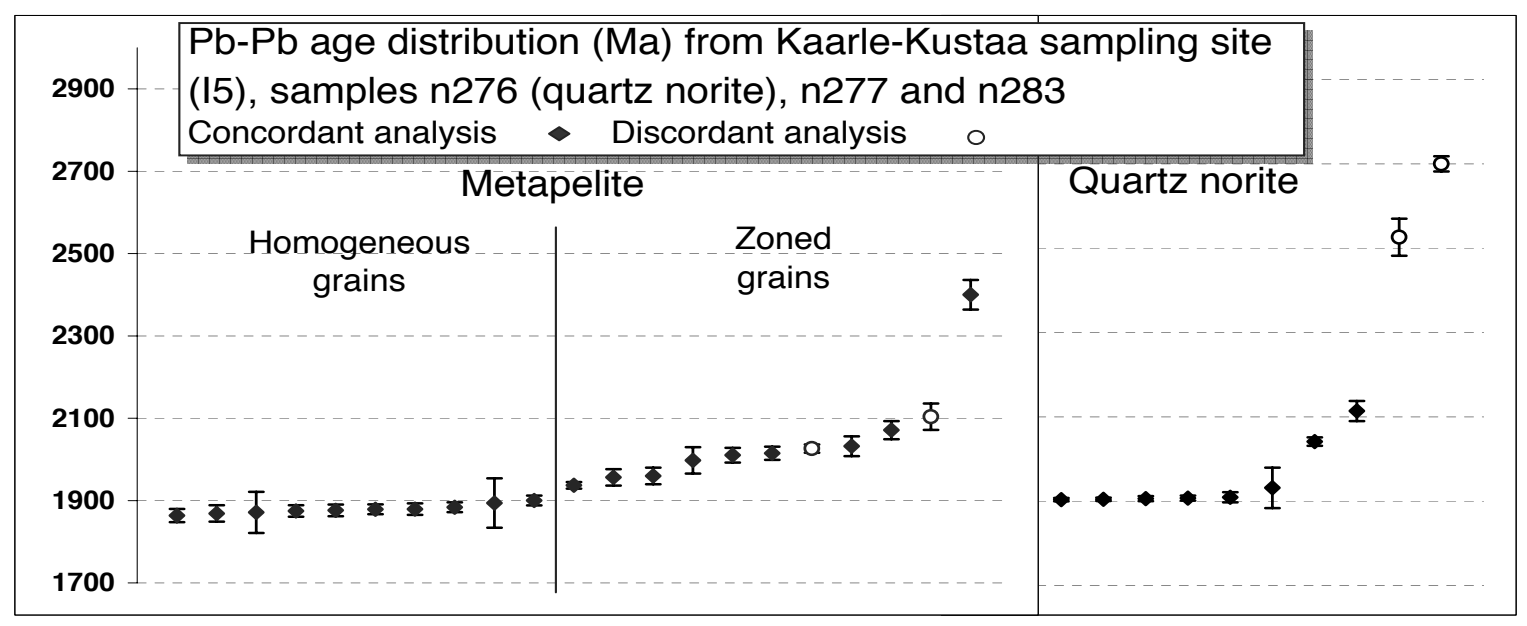

Fig. 4. Distribution of ${ }^{207} \mathrm{~Pb} /{ }^{206} \mathrm{~Pb}$-ages (with $2 \sigma$ error bars) of homogeneous and zoned zircon grains in migmatic metapelite and grains in quartz norite from Kaarle Kustaa sampling site, 15. Black diamonds indicate concordant determinations and white circles discordant.

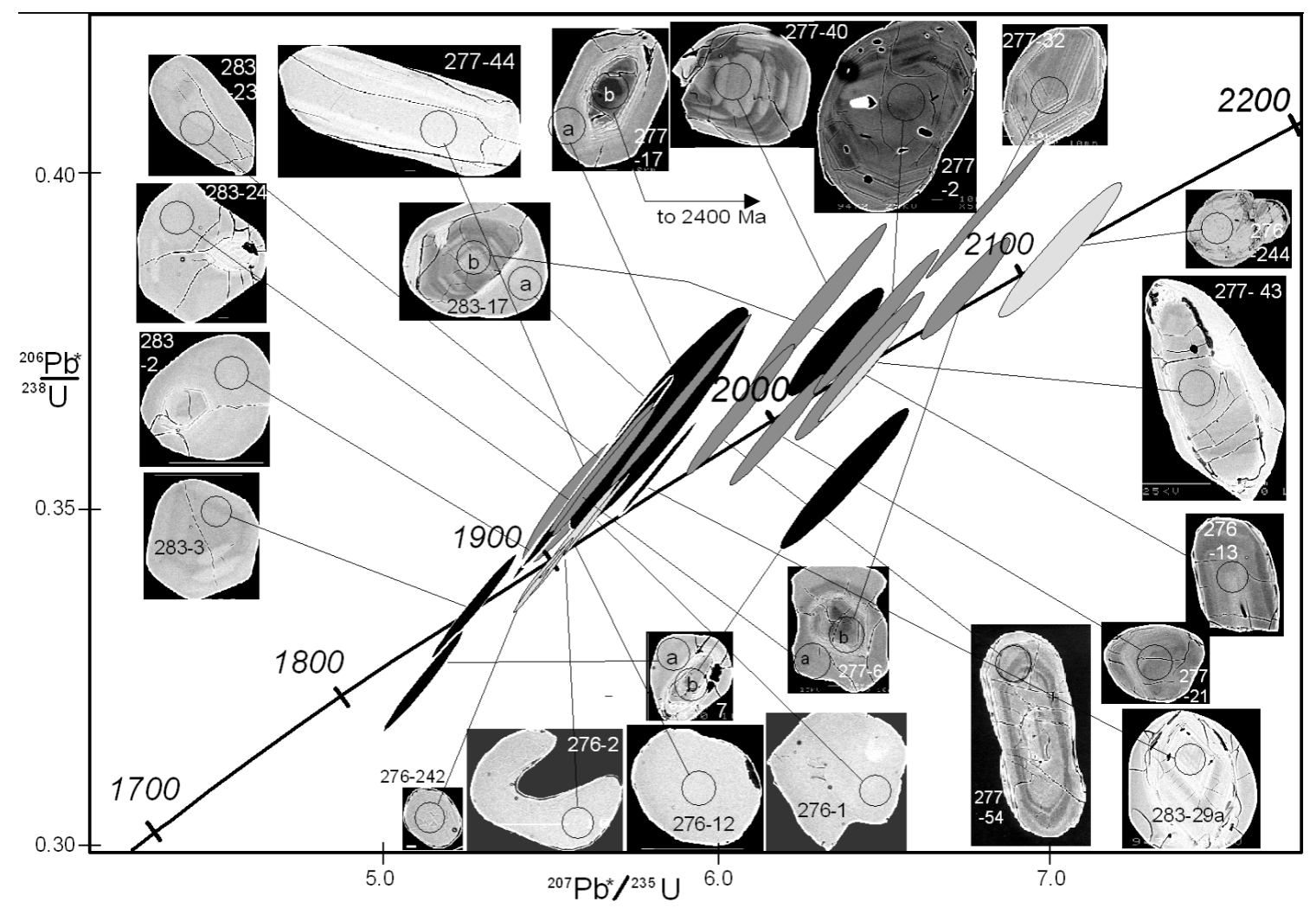

Fig. 5. A detail, between 1700 and $2200 \mathrm{Ma}$, of U-Pb isotope concordia diagram of zircons analyzed from different rock fractions in Kaarle Kustaa sampling site (I5). The color of I $\sigma$ error ellipse shows the lithology: black are zircons from leucosome (NORDSIM numbers n283), grey are from mesosome-melanosome fraction (n277) and light grey are from quartz norite vein (n276). In BSE images, homogeneous and light colored zircons cluster around $1900 \mathrm{Ma}$ and especially those from quartz norite at $1906 \mathrm{Ma}$ while zonal zircons cluster around 2000-2100 Ma, the youngest giving concordant age of $1937 \pm 4 \mathrm{Ma}(I \sigma)$. Note that all rock fractions have 2000-2 I00 Ma age group zircons. 


\subsection{Monazite U-Pb dating}

Monazite separates were obtained from both the leucosome and melanosome from Kuttura (I1.1 and I1.2). Two conventional multi-grain U-Pb analyses were made on both samples. The isotopic data (in Table 3) provide concordant results and give an average age of $1907 \pm 3 \mathrm{Ma}$. The monazite age thus seems to be slightly older than the concordant age range determined for homogeneous zircons of the same samples but, however, similar to the age obtained from the homogeneous zircon of the quartz norite vein (I5.3) at Kaarle Kustaa, some $50 \mathrm{~km}$ apart. The U$\mathrm{Pb}$ ages reported by Meriläinen (1976) for monazite from several granulite samples are close to the age obtained in here.

\subsection{Sm-Nd results}

In the granitic leucosomes, garnet is relatively inclusion-free. Nevertheless, all garnet separates were ground and then leached in order to avoid possible monazite inclusions (DeWolf et al., 1996). Sm-
$\mathrm{Nd}$ analyses on garnet and whole rock were made from the migmatite leucosome at the Kuttura sampling site (I1.1) and leucosome and banded mesosome-melanosome mixture at the Kaarle Kustaa site (I5.1 and I5.2). The data are shown in Table 4 and Figure 7. The three garnet-whole-rock pairs give ages from $1880 \pm 7$ to $1888 \pm 6 \mathrm{Ma}$, i.e. similar age, within the $2 \sigma$ error, at both sampling sites and all parts of the migmatite. This age range partly overlaps the U$\mathrm{Pb}$ age range obtained from the homogeneous zircon grains in all parts of the migmatites at both sampling areas, but is ca. 20 Ma younger than the age of homogeneous zircon in the quartz norite vein at Kaarle Kustaa.

The whole rock $\varepsilon_{\mathrm{Nd}}(1900)$ values are $-2.5,-2.3$ and -2.4 for the samples I1.1 (Kuttura leucosome), I5.1 (Kaarle Kustaa leucosome) and I5.2 (Kaarle Kustaa meso/melanosome), respectively, and the depleted mantle model ages $\mathrm{T}_{\mathrm{DM}}$ range from 2.32 to $2.38 \mathrm{Ga}$. Table 4 also shows the Sm-Nd data from the metasedimentary granulites obtained earlier at the Geological Survey (Huhma and Meriläinen, 1991), which are similar to the results of this work. The quartz norite

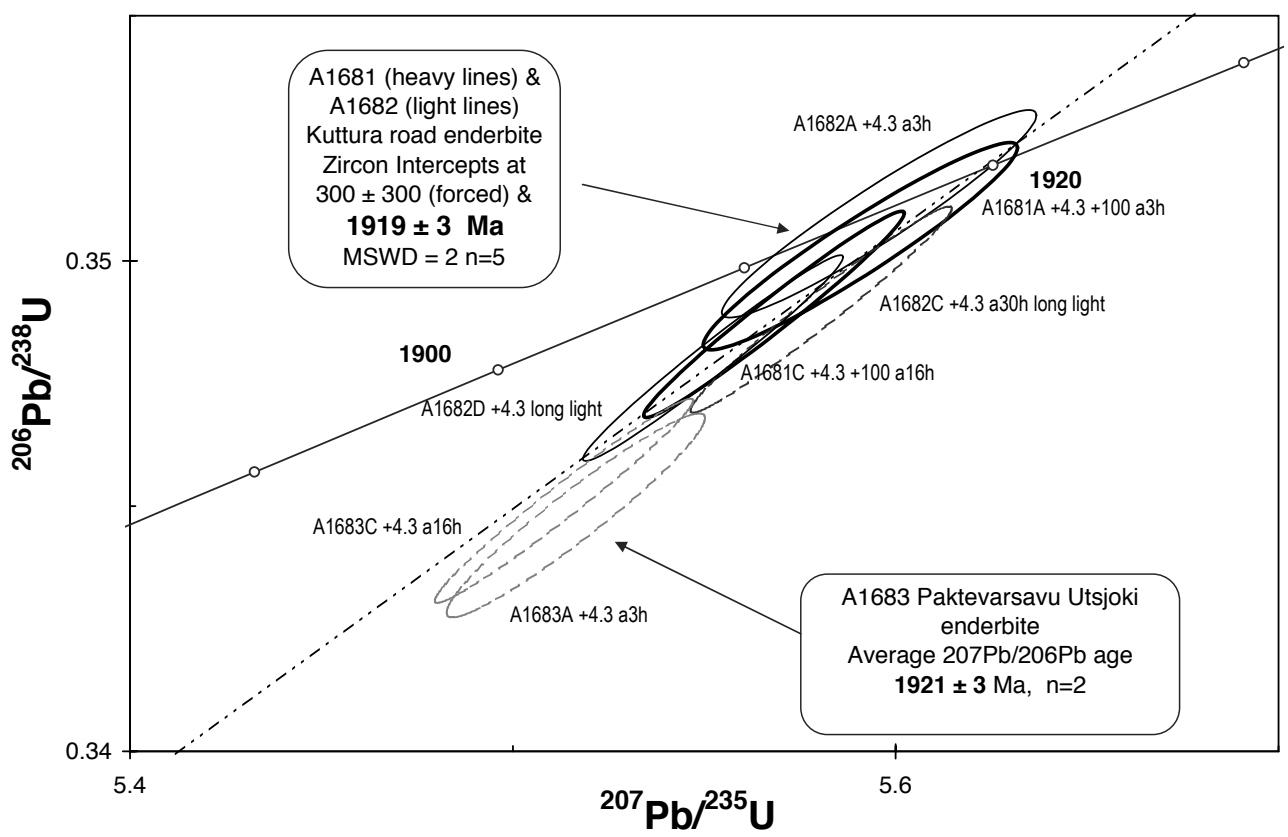

Fig. 6. U-Pb isotope concordia diagram of zircon fractions from the norite-enderbite series samples AI68I-3. 


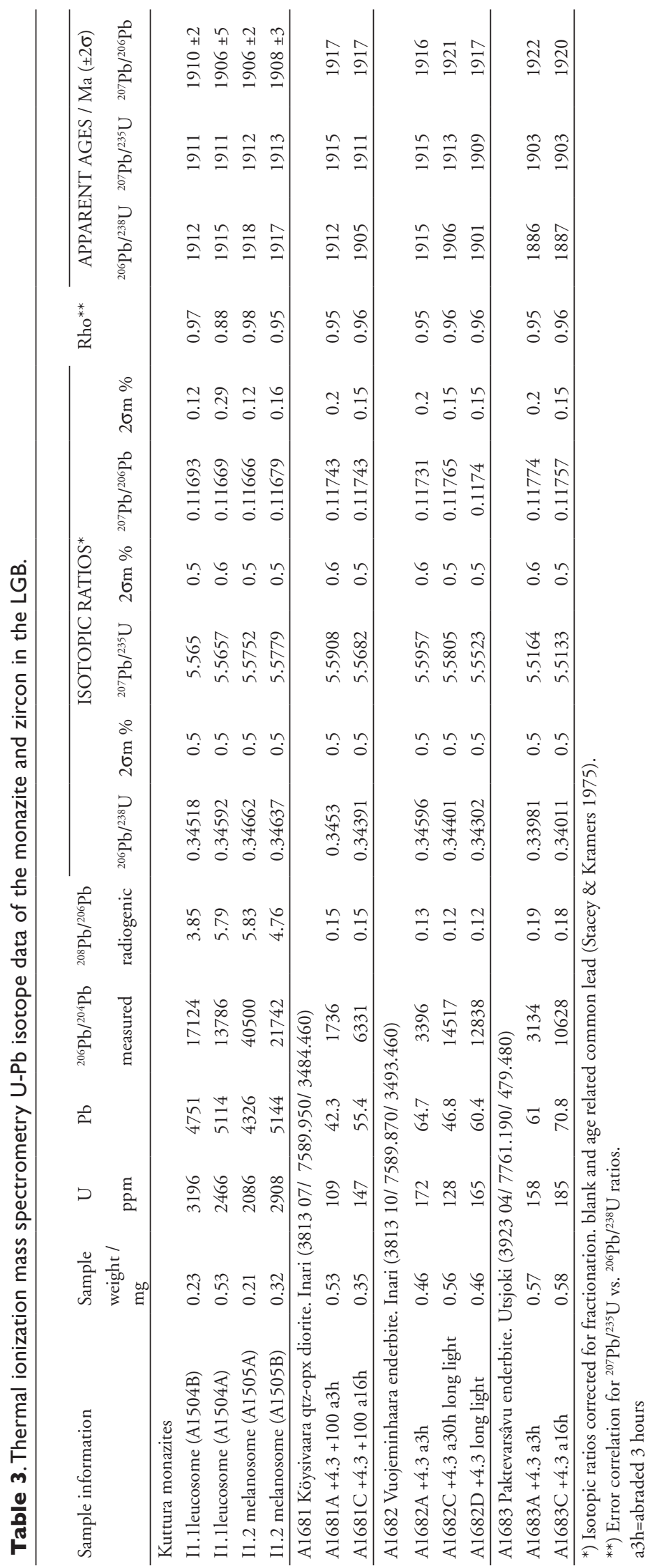




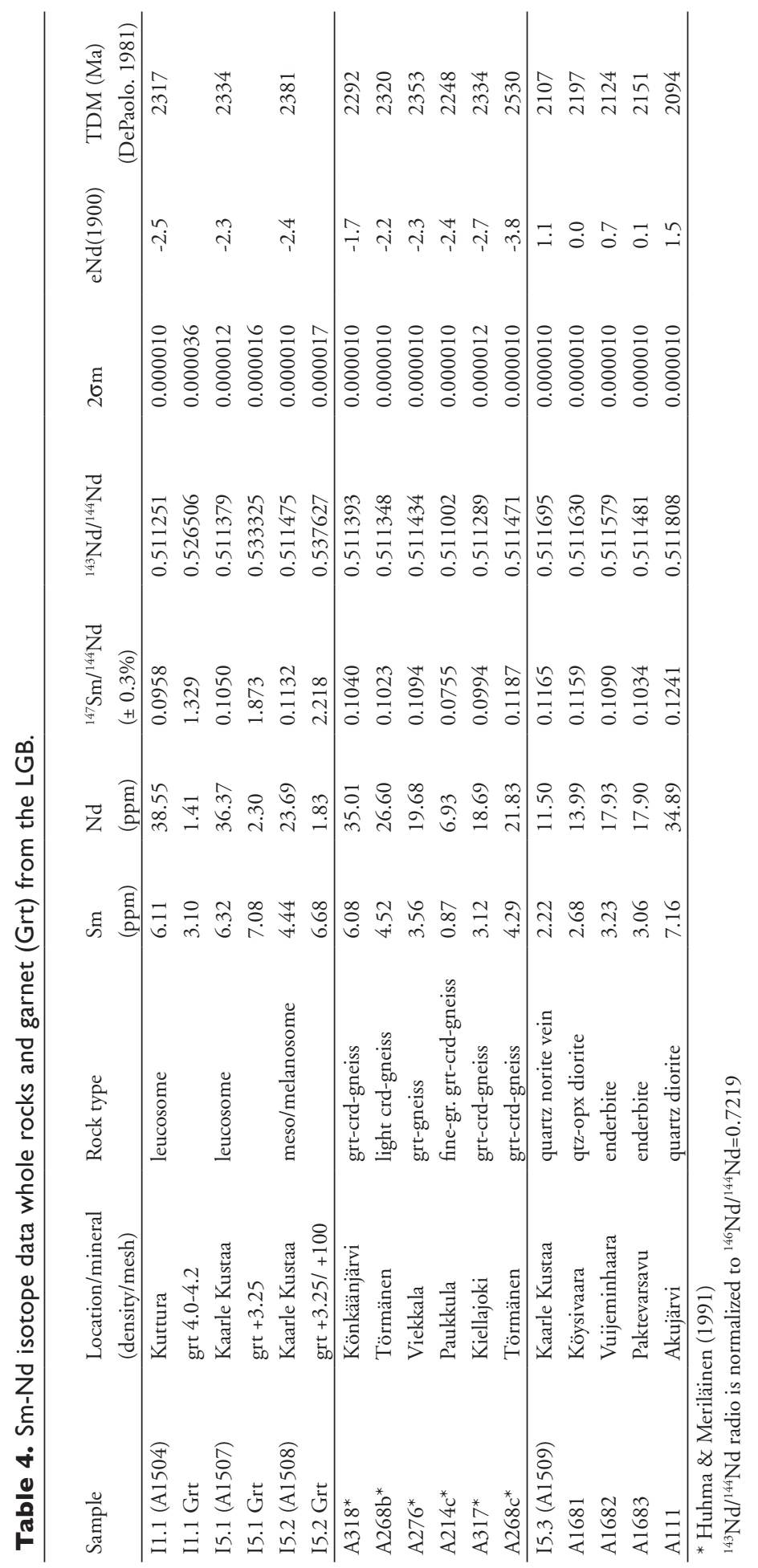




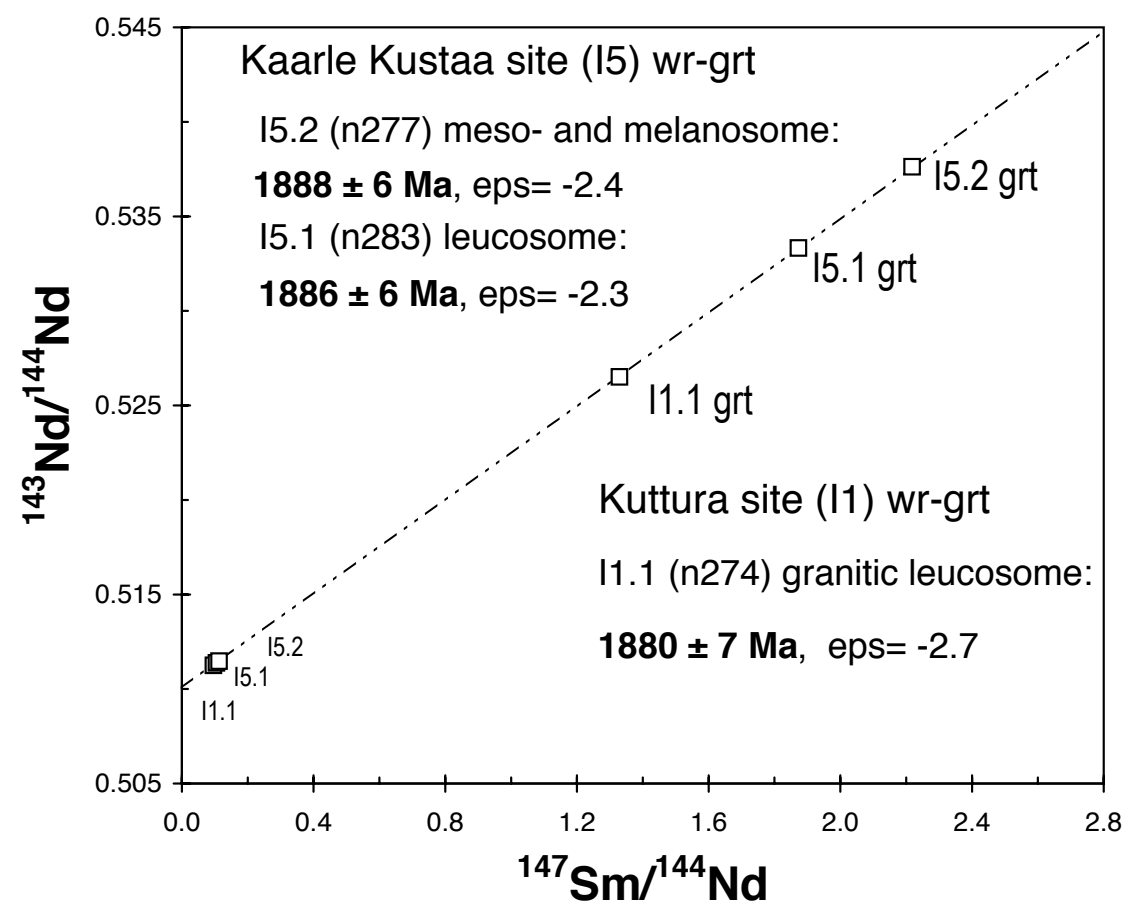

Fig. 7. Sm-Nd isochron of bulk rocks and garnets. Leucosomes and their garnets were analyzed from both Kuttura and Kaarle Kustaa sites and meso-melanosome mixture from Kaarle Kustaa.

vein in Kaarle Kustaa in contrast to the metapelite, has a positive $\varepsilon_{\mathrm{Nd}}(1900)$ value of 1.1 and a depleted mantle model age of $2107 \mathrm{Ma}$. The initial $\varepsilon_{\mathrm{Nd}}$ for the enderbites is close to zero.

\section{Petrogenetic interpretation of the results}

\section{I. Provenance and age of deposition of the LGB metasediments}

The Sm-Nd isotopic studies suggest a substantial Palaeoproterozoic provenance for the metasediments of the Lapland Granulite Belt. The average crustal residence ages $\mathrm{T}_{\mathrm{DM}}$ (DePaolo, 1981) are typically c. 2.3 Ga (Table 4 and 5 in this work; Huhma and Meriläinen, 1991; Daly et al., 2001), which is roughly consistent with the U-Pb zircon data obtained in this and previous studies (Meriläinen, 1976; Bibikova et al., 1993; Sorjonen-Ward et al., 1994).

Zoned zircon grains analyzed in this study are mostly concordant or slightly discordant and yield ages from ca. 1.93 to $2.9 \mathrm{Ga}$. They are interpreted to represent detrital grains in the sedimentary protolith of the metapelites. The rounded shapes and discordance of zoning in the zircon grains provide textural evidence for their detrital origin (Fig. 2). These zoned zircon grains indicate the age distribution of silicic, igneous source rocks of the metasediments, in contrast to the homogeneous grains, which are interpreted to have formed during metamorphic evolution of the rocks (Figs. 3 and 4).

Archaean cratons, which mostly consist of siliceous rocks, formed only a minor source for the LGB metasediments as only three analyzed grains in the leucosome from Kuttura, one concordant and two discordant, have an Archaean age. The ages of the three Archaean zircons are similar to those of the Archaean granitoids in northern Finland (Hanski et al., 2001). This may seem surprising because the LGB is surrounded mostly by Archaean terrains and also 
the Proterozoic belts seem to have an Archaean basement, as revealed by e.g. Sm-Nd data of granitoids (Huhma, 1986; Hanski, 2001; Hanski et al., 2001; and references in op.cit.). At least three explanations may be presented. Firstly, the Archaean areas may not have been exposed during the sediment supply or secondly, sedimentary material was supplied from distant sources across an only partially exposed Archaean basement. These seem to be improbable because in almost all known Archaean-Proterozoic transitions in Fennoscandia, a well-developed sub-aerial weathering crust and regolith is found, having an approximate age of $2.45-2.33 \mathrm{Ga}$ (Sturt et al., 1994). Third possibility is that the LGB sediments were deposited in a distal position relative to the Archaean basement and are clearly allochthonous or even tectonically exotic in its present position.

The majority of the detrital grains, both in Kuttura (I1: 19 grains) and Kaarle Kustaa (I5: 9 grains) sampling sites range in age from 1.96 to $2.2 \mathrm{Ga}$, with most between 2.01 and $2.04 \mathrm{Ga}$. These ages are comparable to the SIMS-results by Sorjonen-Ward et al. (1994) and also consistent with the conventional zircon U-Pb results for the LGB paragneisses (Meriläinen, 1976; Bibikova et al., 1993). Silicic igneous lithologies of this age are, however, unexposed in the Fennoscandian Shield. The Central Lapland Greenstone Belt, situated SW of the LGB has similar age distribution, but is mainly composed of mafic volcanic rocks and intrusions (Hanski et al., 2001). There are also some acid porphyritic dikes among mafic meta-lavas, but they are only few metres wide and thus cannot be the main source of the voluminous siliciclastic metasediments of the LGB. Some marks of silicic magmatism of ca. 2.0 age group are found in the northern part of the shield, for example in the Korkiavaara arkosite formation in the Peräpohja Schist Belt (Hanski et al., 2005) and in the Tersk Terrane orthogneiss (Daly et al., 2001). The $2.0 \mathrm{Ga}$ age group is common among the detrital grains in meta-greywackes of the Svecofennian formations (Huhma et al., 1991; Claesson et al., 1993; Lahtinen et al., 2002; Rutland et al., 2004). In summary, the major provenance of the LGB is from an unknown $2.0-2.1 \mathrm{Ga}$ siliceous igneous terrain suggesting that the LGB is an allochthonous province.

The youngest detrital grains can be used to constrain the age of deposition. In this study these include analyses, which provide ${ }^{207} \mathrm{~Pb} /{ }^{206} \mathrm{~Pb}$ ages of $1922 \pm 14 \mathrm{Ma}, 1958 \pm 8 \mathrm{Ma}$ (I1.3) and $1980 \pm 8$ $\mathrm{Ma}$ in sample I1.3 (Kuttura), $1937 \pm 8 \mathrm{Ma}$ in sample I5.1 (Kaarle Kustaa), and $1956 \pm 20 \mathrm{Ma}$ and $1960 \pm$ $20 \mathrm{Ma}$ in sample I5.2 (Kaarle Kustaa) (Tables 1 and 2, Fig. 5). All these results are nearly concordant, but the youngest of these is more suspect due to relatively high amount of common lead in the analysis. It seems reasonable to state that deposition took place after ca. 1.94 Ga. The LGB palaeobasin was obviously buried as a tectonic mélange between convergent plates before the c. $1.92-1.91 \mathrm{Ga}$ intrusion of enderbites (Tables 4 and 5 in this work; Meriläinen, 1976; Bibikova et al., 1993) The Sm-Nd and detrital zircon $\mathrm{U}-\mathrm{Pb}$ isotopic characteristics of the LGB metasediments are quite similar with the major Svecofennian and upper Kalevian metasediments in southern Finland and Sweden (Huhma, 1987; Claesson et al., 1993; Lahtinen et al., 2002). Thus, a correlation of the LGB protolith with that of Svecofennian metagreywackes cannot be excluded.

\subsection{Evolution and crystallization of the norite- enderbite series magmas}

Tri-modal major element composition of the LGB is evident from the data presented by Eskola (1952), Meriläinen (1976) and Hörman et al. (1980), and reflects the three major rock categories, i.e. the noriteenderbite series, palaeosome parts and granitic leucosomes of the metapelites. This has probably led to some misinterpretation, because the granitic rocks are similar to rhyolitic volcanic rocks in their major element composition. No detailed trace element survey was included in our study, but it is useful to give a short review of earlier studies on the norite-enderbite series (i.e. Barbey et al., 1986; Bibikova et al., 1993). Part of their trace-element data on meta-igneous rocks of the LGB, normalized to the primitive mantle composition, is shown in Fig. 8. The metaig- 
neous rocks make up a continuous spectrum from poorly to highly fractionated, which is probably best seen from the norite data of Barbey et al. (1986) (Fig. $8 \mathrm{~d}$ ), where the $\mathrm{Rb} / \mathrm{Yb}$ ratios vary from 1.5 to 70 . The heavy rare earth element (REE) contents are generally similar to those of oceanic basalts. Large ion lithophile element (LILE) spectra range from values almost as low as those of $\mathrm{N}$-type mid-ocean ridge basalts to as high as those of alkali basalts (see data given by Sun \& McDonough, 1989). In most of the patterns there is a maximum at $\mathrm{Ba}, \mathrm{K}$, and $\mathrm{Sr}$ and often also at $\mathrm{Rb}$ (Fig8a-d) and a clear minimum at $\mathrm{Nb}$ and Ta. In many samples a minimum is also encountered at $\mathrm{Ti}$ and P. Some samples, especially amphibolites, analyzed by Bibikova et al. (1993) have a deep minimum at Th and $\mathrm{Hf}$ (Fig 8b).

The high variation in the trace element patterns, especially in the large ion lithophile element (LILE) part, needs an explanation. Barbey et al. (1986) thought that this variation reflects different kinds of mantle sources partly metasomatized by light rare earth-element- enriched fluids. Another possibility, however, is considered more probable. We calculated a simple mixing model containing enriched MORB (Sun \& McDonough, 1989: EMORB in Table 1) and a typical metasediment of the LGB and found that ca. 15 to $40 \%$ of mixing would alone explain even the highest LILE enrichment in the norite-enderbite series. This would also explain the relatively large negative phosphorus anomaly in their mantle-normalized pattern, which is atypical of mantle-derived but a general feature of crustal rocks (Figs 8e-f). The necessary amount of mixing with metasediments would, of course, be smaller if possible fractionation and/or some mantle heterogeneity were involved in addition to assimilation.

Evidence of assimilation is also given by the Sm$\mathrm{Nd}$ data of the norite-enderbite series. Because the $\mathrm{T}_{\mathrm{DM}}$ ages of the series are ca. $2.1-2.2 \mathrm{Ga}$, apparently large amount assimilation has taken place in these $1.92 \mathrm{Ga}$ old mantle derived rocks (Tables 4 and 5). If we compare the $\mathrm{Sm}-\mathrm{Nd}$ model age of norite-enderbite series with the age $2.3-2.4$ Ga obtained for the surrounding migmatites and suppose that the mag- ma was derived from the mantle slightly before its crystallization, ca. $40-50 \%$ of mixing with Sm and $\mathrm{Nd}$ from migmatites is necessary. $15-20 \%$ of mixing of metapelite material into the magma, having a composition roughly that of mid-ocean ridge basalts (MORB), would be sufficient for this. Assimilation is probably a common feature in island arc magmas. For example Chen et al. (1999) observed even $70 \%$ of mixing of older material in the recent Unzen magmas. Additional evidence for mixing in the LGB is also given by the quartz norite vein at Kaarle Kustaa, which contains a substantial amount of inherited zircon, ranging in age from Palaeoproterozoic (1.96$2.2 \mathrm{Ga}$ ) to Archaean (Table 2). Finally, assimilation is also strongly supported by direct field evidence. As described before, the contacts between enderbites and metapelites are often gradual and transitional rock types often exist between metaigneous and metapelitic rocks.

The two large intrusions are dated here to be ca. $1.92 \mathrm{Ga}$ (Tables 3 and 5), which is close to the age obtained by Meriläinen (1976) and Bibikova et al. (1993). The quartz norite vein studied by SIMS seems to be slightly younger in age, viz ca. 1.91 Ga. No grains giving the age of ca. 1.92 Ga were found in the vein. All five homogeneous zircon grains dated in it are concordant, have small errors and give an age of $1906 \pm 4 \mathrm{Ma}$. Because a similar, concentrated age population was not obtained from the enveloping migmatites, the age probably represents a process that took place in the vein, but not in the migmatites. We consider that the grains represent syn-intrusive crystallization at granulite facies conditions. The homogeneity of these grains probably reflects their stable crystallization conditions in the lower crust during high-grade metamorphism. Thus, the age of the vein would represent the latest stage of intrusion of the norite-enderbite series during the peak of granulite-facies metamorphism of the LGB.

It is thus evident that a volcanic arc with variably assimilated magmas existed at ca. $1.92 \mathrm{Ga}$ between the Karelian province, now in the south and southwest, and the Kola Province, now in the northeast of the LGB. 

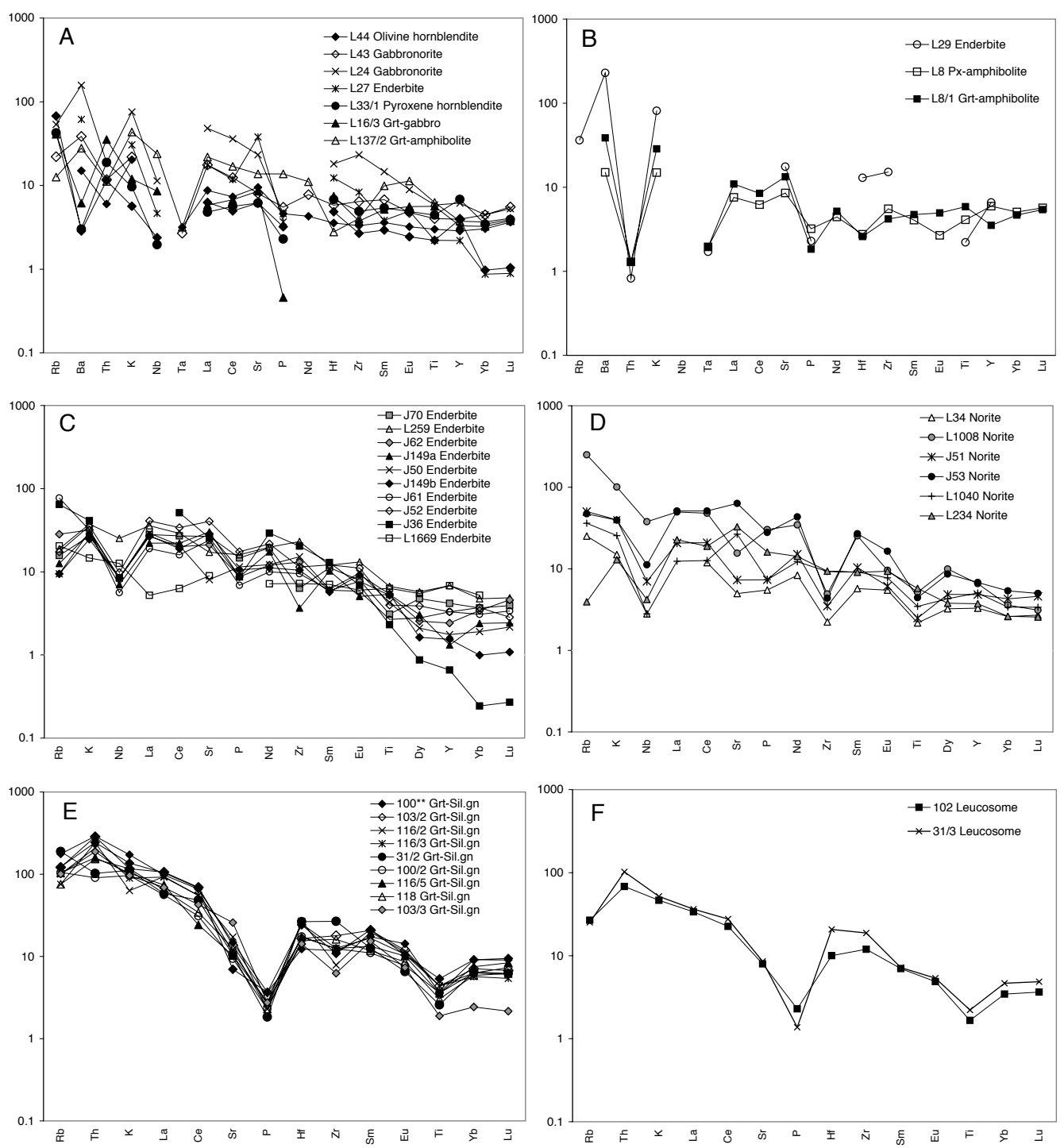

Fig. 8. Mantle normalized trace element diagrams of the LGB. Data for A and B are from Bibikova et al. (I993) and the rocks were interpreted by them to represent charnockite complex, viz. norite-enderbite series of the present paper. $C$ and D give data of Barbey et al. (1986) for enderbites and norites, respectively. E and $F$ give data from metapelites by Bibikova et al. (1993). Data for E are from garnet-sillimanite gneisses (blastomylonitic palaeosome-neosome mixtures), and data for $F$ are from granitic leucosomes. Normalization values are from Sun and McDonough (1989).

\subsection{Metamorphic evolution of the migmatitic metapelites}

The detrital zircon data of the LGB show, that the deposition of the metasediments took place after ca. $1.94 \mathrm{Ga}$ (Tables 1 and 2). As shown above and in part I (Tuisku et al., 2006), norites and enderbites intruded into the metasediments ca. $1.92-1.91 \mathrm{Ga}$ ago in relatively high pressure. On the other hand, it seems that the metapelites were heated during the burial because sillimanite is the prevailing prograde aluminium silicate (Tuisku et al., 2006). Considering these observations, and taking into an account the great volume of the igneous rocks in the LGB, the evolution of the metapelites may be explained by a model, 


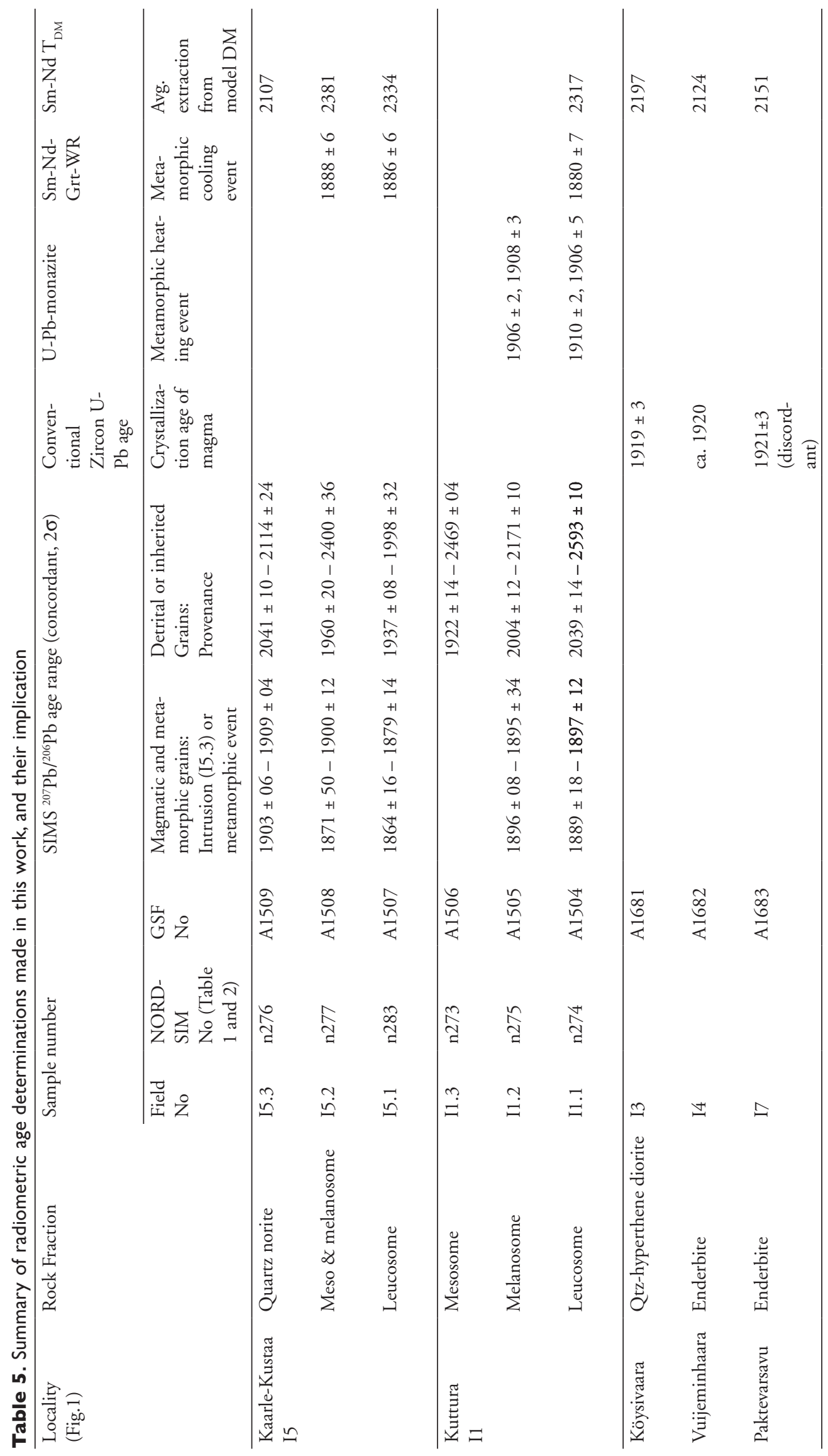


where the pelites were buried deeply soon after deposition and, at the same time, intruded and heated by the norite-enderbite magma. If this model is accepted, the burial and heating took place within less than ca. 20 - 30 million years from ca. 1.94 to 1.91 $\mathrm{Ga}$, which is comparable to the time scale of similar modern tectonic processes (Hsü, 1989; Wallis et al., 1998). In summary, the progressive part of the metamorphism of the LGB was a combined process of rapid burial and heating by magmas with volcanic arc affinity. Most probably, this took place in a subduction setting, which could explain both the burial rate of the sediments and arc affinity of the magmas.

Monazite and zircon U-Pb data from the metapelites provide further evidence for metamorphic evolution. The monazite $\mathrm{U}-\mathrm{Pb}$ age of the metapelites overlaps the intrusion age range (Meriläinen, 1976; this study, Table 3 ) and the crystallization of monazite in migmatites may be connected with the prograde, heating stage of regional metamorphism. When the growth of monazite in leucosome walls is considered, it apparently crystallized during dehydration melting of the metapelites and early stage of leucosome and anatectic dyke formation at ca. 1.91 Ga.

The homogeneous zircon grains and rims around detrital cores in the migmatitic metapelites form a relatively uniform ${ }^{207} \mathrm{~Pb} /{ }^{206} \mathrm{~Pb}$ age population between $1900 \pm 12$ and $1864 \pm 16 \mathrm{Ma}$ (Tables 1 and 2, Figs 35). The granulite-facies metamorphic cycle of the metapelites is the most probable process to have generated such zircon. The youngest zircon ages are obtained especially for the leucosomes of the migmatites ( $\mathrm{Ta}$ bles 1, 2 and 4, Fig. 5). We conclude that some of the metamorphic zircon grains crystallized during the decompression and cooling of the migmatites, until the leucosomes were completely solid at lower pressures and temperatures as shown by Tuisku et al. (2006). It is also possible that in the beginning of decompression more melt was being generated (i.e. Tuisku et al., 2006: reactions 4-7; Whitehouse \& Platt, 2003).

Monazite thus crystallized before zircon. Zircon generally maintains the age of the first high temperature crystallization regardless of the complexity of the geological history of the rock, but may some- times form even in a relatively low temperature in the presence of proper fluid (Gebauer \& Grünenfelder, 1976). Cooling, crystallization of leucosomes and liberation of fluid in the end apparently had no effect on the monazite $\mathrm{U}-\mathrm{Pb}$ system. The closure of the monazite U-Pb system has been a matter of debate (see e.g. Villa, 1998) but many recent studies indicate that $\mathrm{Pb}$ diffusion in monazite may be slow enough to the prevent resetting up to temperatures of $820^{\circ} \mathrm{C}$ (Spear $\&$ Parrish, 1996; Parrish \& Whitehouse, 1999; Schaltegger et al., 1999; Vavra \& Schaltegger, 1999; Jung and Metzger, 2001).

The garnet-whole rock $\mathrm{Sm}-\mathrm{Nd}$ data for migmatites provide ages from $1880 \pm 7$ to $1888 \pm 6 \mathrm{Ma}$ (Table 4). Similar results were recently obtained by Daly et al (2001), who reported a Sm-Nd garnet-whole-rock age of $1870 \pm 7 \mathrm{Ma}$ for a migmatite sample. It seems that the leucosomes and garnet crystallized relatively late: wet granite crystallization temperature at $2 \mathrm{kbar}$ is about $675^{\circ} \mathrm{C}$, which is about $175^{\circ} \mathrm{C}$ lower than the peak temperature of metamorphism in the LGB (Tuisku et al., 2006). The late crystallization of garnets of the leucosomes is supported by textural evidence, as they do not contain sillimanite inclusions despite of ubiquity of this mineral, which is a rule in the palaeosomes. This suggests that the majority of leucosome material remained liquid for a relatively long time and crystallized over ca. 10 to $30 \mathrm{Ma}$, until the complete solidification took place near the water saturated melting curve of granite around $1.88 \mathrm{Ga}$ ago.

The young zircon $\mathrm{U}-\mathrm{Pb}$ and garnet-WR Sm-Nd ages might also been caused by fluid liberated from the leucosomes during crystallization. According to the experimental data of Holtz et al. (2001), granitic melt may contain 4 to $5 \%$ of water at $800-$ $850^{\circ} \mathrm{C}$ and $6.5-8.5$ kbar. Because the LGB leucosomes mostly crystallized below the stability curve of reaction $\mathrm{Ms}+\mathrm{Qtz}=\mathrm{Or}+\mathrm{Al}_{2} \mathrm{SiO}_{5}+$ vapor, all fluid was liberated during the crystallization process ( $\mathrm{Tu}-$ isku et al., 2006). Definitively, the effect of fluid on isotope systems would be seen first in leucosomes. It has been observed that isotope systems of different rocks obviously have been closed or reset in different temperatures, which may vary according to the geo- 
logical history, rock type, grain size and fluid activity (Mezger et al, 1992; Burton et al., 1995; Jung \& Mezger, 2001; Thöni, 2003). The garnet-WR Sm$\mathrm{Nd}$ age in the meso- and melanosome is quite similar to those in leucosomes (Table 5). It is probable that the fluid activity lead to resetting of the Grt-WR system in these parts of the rock during leucosome crystallization.

Zircon data also provide evidence for the origin of leucosomes. There is no apparent difference in the age range of zoned zircons between different fractions of the migmatitic metapelite. This shows that granitic material of leucosomes was derived, including inherited detrital zircon, by melting and segregation from the adjacent mesosomes. This is compatible with the initial $\varepsilon_{\mathrm{Nd}}$-value, which is the same in leucosome and melanosome (Table 4). In this case, zircon may clearly be used as a tracer for the protolith of melts.

In the LGB, observations on zircon zoning combined with isotope data are key to the history of isotope systems. Zircons of the leucosomes have old detrital cores with variable $\mathrm{U}-\mathrm{Pb}$ ages and shapes evidently resulting from abrasion during sediment transport. The rims seem to have grown over the cores, separated from them by a sharp boundary and in many cases by a mantle of inclusions. Thus the population of homogeneous zircon rims must obviously have formed by crystallization from leucosome melt or fluid, not resetting of previous zircons, which evidently remained unaffected. It should also be noted that the border of the core and rim is always sharp, which has been used as a strong argument against resetting by diffusion (Hawkins \& Bowring, 1999). Thus the ages of the homogeneous zircons may be interpreted to represent a real crystallization age spectrum of new zircon, which most probably took place during the cooling and crystallization process of the leucosomes at ca. 1.90 - $1.88 \mathrm{Ga}$ ago.

Figure 9 summarizes the evolution of the LGB. The burial began after ca. 1.94 Ga and the belt was intruded by arc magmas at ca. 1.92. The exhumation of the LGB from the site of high-grade metamorphism in lower crust into the upper crust, with cooling from ca. $850^{\circ} \mathrm{C}$ to less than $650^{\circ} \mathrm{C}$, took about
20 - $30 \mathrm{Ma}$ from ca. $1.91-1.90$ to $1.88 \mathrm{Ga}$. Different isotope systems were closed due to mineral crystallization in different T, $\mathrm{P}$ and fluid environment, excluding the fluid triggered resetting of the garnet-WR $\mathrm{Sm}-\mathrm{Nd}$ system of the palaeosomes.

\subsection{Metamorphism of enderbite-norite series}

As described in part I (Tuisku et al., 2006), reaction textures in enderbites and norites were generated due to decompression and cooling. Thermobarometry, homogeneous minerals, lack of lower grade inclusions, rock texture and field relations also suggest that the norite-enderbite series crystallized within the same conditions where metapelites suffered the maximum temperature of metamorphism (Tuisku et al., 2006). This is further supported by assimilation of magmas, discussed above. Evidently, the igneous series subsequently shared the evolution with the metapelites, cooling and decompressing together with them in the following 30 million years. It seems that the zircon $\mathrm{U}-\mathrm{Pb}$ isotopic system in metaigneous rocks records mostly the crystallization age of the intrusions (i.e. ca. $1.92-1.91 \mathrm{Ga}$ ) and the long granulite-facies and cooling history had little effect on it.

\section{Tectonic consequences and corre- lation}

The Palaeoproterozoic rocks in the Fennoscandian Shield are divided into the Karelian and Svecofennian formations (Korsman et al., 1997). The former occupy the area south and southwest from the LGB, together with Archaean basement blocks and some Svecofennian formations. The Karelian formations consist of intracratonic, rift and marginal ocean basin sediments with abundant, mostly mafic igneous rocks. Volcanic rocks to the SW of the LGB give ages from $2438 \pm 8$ to $1880 \pm 8 \mathrm{Ma}$. The youngest ages have been obtained from felsic metavolcanics with simultaneous quartz monzonite intrusions (Manninen et al., 2001; Rastas et al., 2001). The youngest detrital zircon grains in the Karelian metasediments are about $1930 \pm 24 \mathrm{Ma}$ old, while the oldest are Ar- 


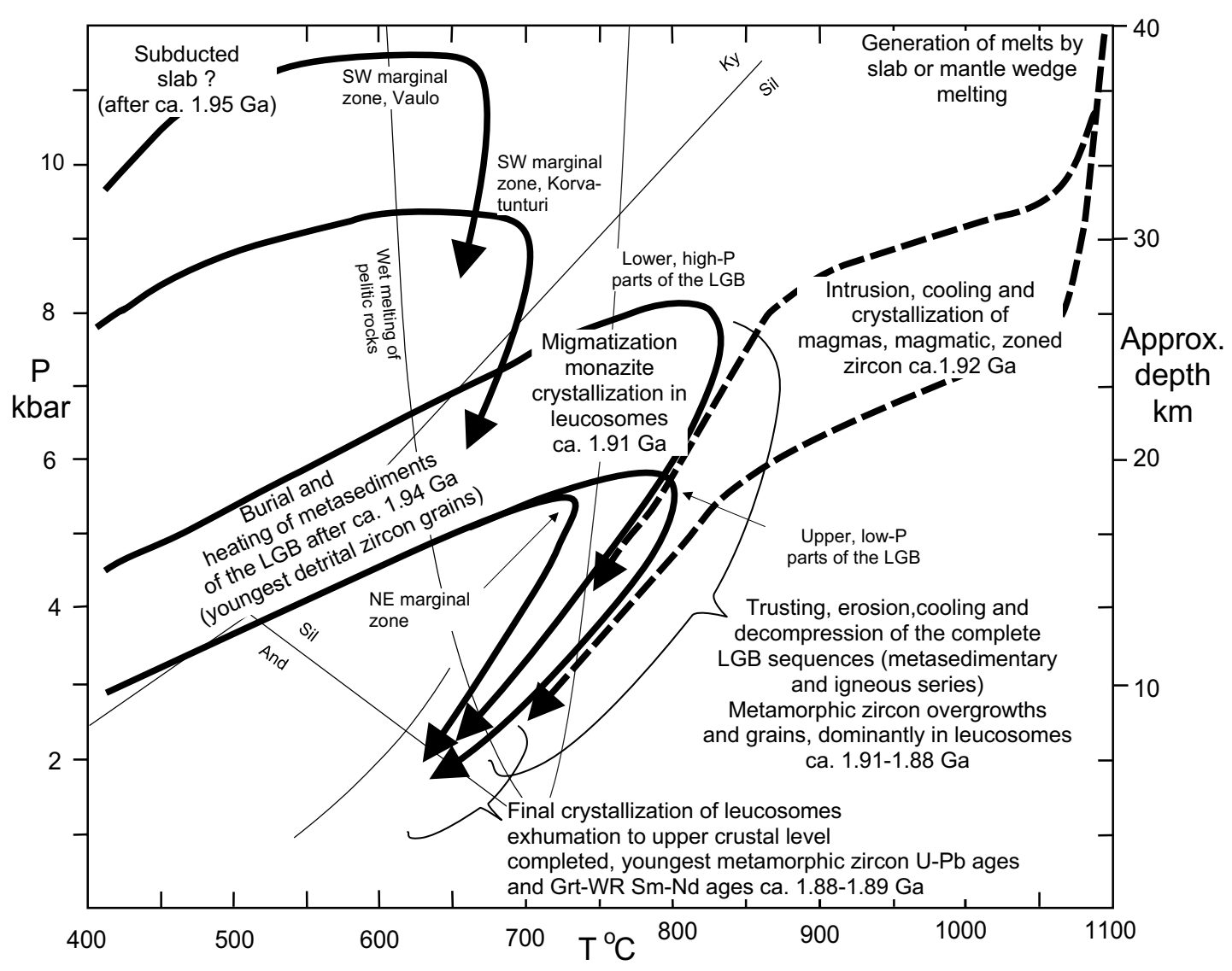

Fig. 9. Summary of the evolution of the LGB. The diagram shows PTt evolution of major metamorphic and igneous rock series of the belt. Evolution of the marginal zones of the LGB is also shown. See text for further explanation.

chaean (Huhma et al., 1991; Claesson et al., 1993). Based on the Sm-Nd isotopes, the mean crustal residence age of these "upper Kalevian" metasediments is similar to that of the metapelites of the LGB, being about 2.2 - 2.3 Ga (Huhma, 1987; Huhma and Meriläinen, 1991). This suggests that the sedimentary basin where the LGB greywackes accumulated could be comparable to the ocean basins now expressed by the presence of Outokumpu and Jormua $1.953 \pm 2 \mathrm{Ga}$ ophiolites (Huhma, 1986; Peltonen et al., 1998). The Karelian rocks SW from the LGB were clearly folded before, and the fold structures were transposed during the thrusting of the LGB to the southwest (Korja et al., 1996).
The Svecofennian formations occupy the central and southwestern part of the shield, more than 350 $\mathrm{km} \mathrm{SW}$ from the LGB, and are considered a tectonic collage of at least two juvenile arc complexes and a turbidite dominated basin between them (Gaál \& Gorbatschev, 1987; Korsman et al., 1997). Sm-Nd and SIMS zircon studies show that an Archaean component may be found in the arc sediments and the majority of detrital zircons are older than 1.9 Ga (Huhma, 1987; Huhma et al., 1991; Claesson et al., 1993; Lahtinen et al., 2002; Rutland et al., 2004). This may indicate a prolonged arc evolution already before 1.9 $\mathrm{Ga}$ or involvement of an unknown (orogenic?) supply. The age of the syntectonic igneous rocks in the 
Svecofennian domain varies from 1.93 to $1.85 \mathrm{Ga}$ but is weighted at $1.88 \mathrm{Ga}$ (Huhma, 1986; Claesson \& Lundqvist, 1995; Romer \& Öhlander, 1995; Korsman et al., 1997), which means that the Svecofennian igneous activity partly overlaps the activity in the Karelian domain. The post-tectonic granitoids are younger than $1.83 \mathrm{Ga}$. The greater part of these young granitoids occurs in the area occupied by the Karelian supracrustal sequences and they also crosscut the LGB and the Archaean basement areas (Meriläinen, 1976).

The palaeobasin of the LGB pelite sequence was active within a period between ca. 1.95 and $1.92 \mathrm{Ga}$ ago and the norite-enderbite series formed at ca. 1.92 $-1.91 \mathrm{Ga}$ ago. The basin and igneous rock series may thus be correlated chronologically with the early Svecofennian sedimentary and igneous formations in the southern and western part of the shield. The oldest Svecofennian syntectonic plutonic rocks, representing the primitive calc-alkaline arc, are ca. $1.92 \mathrm{Ga}$ old, similar to the norite-enderbite series. In addition, the age distribution of LGB detrital zircons is almost identical to that of some Svecofennian metagreywackes. Thus the palaeobasin evolution may be correlated with Svecofennian tectonic, arc related processes.

The major sediment supply into the LGB palaeobasin was from $2.2-1.97 \mathrm{Ga}$ old siliceous sources, which are practically unknown in Fennoscandian shield. This source problem has also been encountered with the Svecofennian metagreywackes (Huhma et al., 1991; Claesson et al., 1993; Lahtinen et al., 2002) and metamorphosed sedimentary formations in the other parts of the world (Friedl et al., 2000; Lee et al., 2000; Murphy \& Hamilton, 2000; Mapeo et al., 2001; Scott et al., 2002). The $2.2-2.0 \mathrm{Ga}$ source could thus be traced in eastern North America because it has been proposed that the $-1.9 \mathrm{Ga}$ evolution may be correlated on both sides of the Atlantic Ocean (Hall et al., 1995). There are some relatively small silicic units, mostly separate granitic intrusions of this age, in North Atlantic realm, like in the basement of the Caledonides of Greenland and in the southeastern Churchill Province in Labrador
(Kalsbeek et al., 1999; Wardle et al., 2002a). These are too small in size to have been the major source of supply for such a large basin as the LGB protolith. Larger occurrences of silicic igneous rocks as well as signs of high-grade metamorphism of this age group are found elsewhere on the Earth, especially in South America in the Transamazonian belts and related belts in Western and Central Africa (Dada, 1998; Feybesse et al., 1998; Hartmann et al., 1999; John et al., 1999; Norcross et al., 2000; Plá Cid et al., 2000; Nomade et al., 2002). Also, larger occurrences of this age group are found in Eastern Asia in Korea and the North China Craton (Cheong et al., 2000; Zhao et al., 2000). Signs of ca. 2 Ga orogenic rocks are also found in the basement of the East European Craton (Claesson et al., 2001). The dominancy of the $2.2-$ 1.97 detrital zircons in the LGB and Svecofennian metagreywackes suggests that when making plate tectonic reconstructions during basin filling at ca. 1.941.92 we should probably seek the proximity of some of these areas to Fennoscandia, instead or in addition to Greenland and eastern North America.

The basin development and sediment accumulation in the palaeobasin of the LGB must have been fast because the youngest detrital grains are less than $1945 \mathrm{Ma}$ old, and the basin was already tectonically buried and intruded by quartz noritic magma at ca. 1920 Ma. The metamorphic evolution cycle of the LGB, i.e. burial, heating, exhumation and cooling was also fast. If we suppose that the burial began at ca. $1925 \mathrm{Ma}$, to let the source rocks of youngest detrital zircon grains to be exhumed and eroded and zircons to be deposited, it took altogether ca. $45 \mathrm{Ma}$ to bury the rocks to a depth of twenty to thirty kilometres, heat them up to $850^{\circ} \mathrm{C}$, and finally, exhume to less than ten kilometres depth and cool to ca. $650{ }^{\circ} \mathrm{C}$ at $1880 \mathrm{Ma}$ ago. These features most probably imply that the LGB sediments accumulated in a deep marine trench basin in an active margin, were captured by the subducting plate, intruded by the enderbite-norite series arc magmas and finally exhumed due to uplift and erosion of a mountain belt. Thus, the evolution cycle of the LGB seems to have been similar to in recent orogens whose evolution was driv- 
en by plate collision and associated tectonic processes (Daniel et al., 2003; Searle \& Godin, 2003; Harris et al., 2004).

The orogenic evolution of the LGB may be considered part of the Svecofennian orogeny, which had its most active phase between 1.93 and $1.87 \mathrm{Ga}$ in Finland. The ca. $1.92-1.91 \mathrm{Ga}$ norite-enderbite series of the LGB has the same age as the pre- or syntectonic tonalites of the primitive arc complex of Central Finland, dated at 1.93-1.91 Ga (Vaasjoki et al., 2003). The supracrustal sequences of the primitive arc are considered $1.92-1.88 \mathrm{Ga}$ old and the active arccontinent collision phase $1.89-1.87$ Ga old (Korsman et al., 1997 and 1999), which is similar to the exhumation stage of the LGB, obtained in the present study. The difference between the Svecofennian orogen and the LGB is that the LGB evolved within a relatively short period of time around $1.9 \mathrm{Ga}$. Its evolution was terminated in an oblique continent-continent collision between the Karelian terrain and Kola Peninsula terrain at the NE edge of Karelian terrain (Korja et al., 1996), while the Svecofennian orogen evidently was built up over a longer interval by accretion of separate arc complexes at the SW edge of the cratonic nucleus. There is not much evidence for continent-continent collision at this margin (Korsman et al., 1997 and 1999).

During the last decades ideas of intercontinental correlation from Torngat and Trans-Hudson orogens in the Canadian Shield, through the Nagssugtoqidian belt in Greenland to the so-called Lapland-Kola mobile belt in the Baltic Shield have been presented (Hoffmann, 1989; Bridgwater et al., 1990, 1996; Connelly \& Mengel, 2000, see inset in Fig. 1.). In these models the LGB would be an internal part of the belt with about 1.95 - 1.92 Ga calc alkaline arc magmatism, and would be bordered by major thrust zone(s) of the orogen (Bridgwater et al., 1996). Therefore, as mentioned in the introduction, it is extremely important to obtain radiogenic isotope data from the LGB, and, also to try formulating petrogenetic implication of the data to see whether these kinds of models are justified.

The age of the norite-enderbite series of the LGB is similar to $1.92 \mathrm{Ga}$ Arfersiorfik quartz diorite and
Sisimiut charnockites of the Nagssugtoqidian belt in Greenland. Correlation of the igneous event of the LGB to Greenland is thus justified on a geochronological basis (Kalsbeek \& Nutman, 1996; Whitehouse et al., 1998). However, later tectonic and thermal events evident in the Nagssugtoqidian belt are lacking in the high-grade rocks of the LGB. The assembling of Nagssugtoqidian took place at ca. 1850 to $1820 \mathrm{Ma}$ (Kalsbeek et al., 1987; Kalsbeek \& Nutman, 1996; Connelly \& Mengel, 2000; Connelly et al., 2000) and was considerably later than the $1910-$ $1880 \mathrm{Ma}$ assembling event in the LGB. The Greenland events are thus not correlated to the thrusting and exhumation event of the LGB, even if diachronous assembling were to be considered, and it is evident that Hoffman's (1989) construction needs refining in this respect. It should be noted, that the observations of Daly et al. (2001) in the Tersk Terrane demonstrate a similar age of cooling in the Kola Peninsula as in the LGB, and similarly show the difference between Greenland and the northern Fennoscandian Shield.

If we go further west to North America, and the Canadian Shield (i.e. Torngat Orogen), it may be stated that in relation to the LGB, the same applies as with Greenland, which is closely correlated with eastern North America (Wardle et al., 2002b and references therein). Ca. 1.9 Ga arc magmatism is widespread in the Torngat Orogen and may be chronologically correlated to the LGB, but again, the orogenic deformation is much younger in the Torngat than in the LGB. According to Wardle et al. (2002b; and references therein), even arc magmatism is considerably younger, i.e. $1865-1800 \mathrm{Ma}$, in other orogens of the eastern North America.

However, arc magmatism and deformation of about the same age or slightly older as in the LGB are found in the Taltson-Thelon magmatic zone in the Western part of the Canadian Shield (Bostock \& van Breemen, 1994; Plint \& McDonough, 1995; Ross et al., 1995) and in the Aldan Shield (Frost et al., 1998). In the western Canadian Shield, $2.3-2.0$ Ga juvenile crust is present in the Wopmay orogen, which could be potential a provenance for the sedimentary 
protoliths of the LGB metapelites (Hoffman, 1988). Also, the first two arc episodes of the Wopmay orogen overlap the arc and granulite-facies evolution of the LGB (Bowring \& Podosek, 1989; Bowring \& Grotzinger, 1992). As proposed by Frost et al. (1998), the Aldan and western Canadian Shields could be linked, but, according to our data, the LGB could possibly be added to that linkage. It is quite evident that the intercontinental correlation of terranes having different protoliths, different metamorphic and accretion history is often possible only after their final juxtaposition during crustal assembly. Friend and Kinny (2001) actually showed this for the Lewisian Complex of Scotland. It is also evident that even if we have terranes of approximately the same protolith or metamorphic age side by side in this kind of late assembly, the age criteria alone does not prove their past close relationship.

\section{Conclusions}

The geological history of the LGB is bracketed in this work from deposition (1) to burial and HT metamorphism (2), and further to exhumation of the belt and low-P crystallization of the migmatite leucosomes (3). Important constraints for these are 1) the age of the youngest detrital zircon grains (around $1.94 \mathrm{Ga}$ ); 2) the age of the oldest metamorphic, homogeneous zircon grains and monazite grown during the high-temperature metamorphism (around $1910 \mathrm{Ma}$ ) as well as the age of the norite-enderbite series rocks $(-1920-$ $1906 \mathrm{Ma}$ ); and 3) the crystallization age of homogeneous zircons in the leucosomes $(\sim 1900-1880 \mathrm{Ma})$ and their garnet-whole rock $\mathrm{Sm}-\mathrm{Nd}$ ages $(-1890-$ $1880 \mathrm{Ma})$. Mineral assemblages and thermobarometry determined the metamorphic conditions, viz. $850^{\circ} \mathrm{C}$ and $6-8 \mathrm{kbar}$ in HT stage (2) and $-650^{\circ} \mathrm{C}$ and $2-3 \mathrm{kbar}$ in the LP stage of leucosome crystallization (3). Our data also have implications for the evolution of other decompressing granulite belts. Crystallization of melts and cooling of the rocks unquestionably takes time, especially if mantle derived melts are important heat sources for the metamorphism. In the LGB, cooling lasted ca. $20-30 \mathrm{Ma}$, during which the belt was exhumed from lower and middle to upper crustal levels. A similar evolution has also been demonstrated in other metamorphic belts. Hawkins and Bowring (1999) showed that it took ca. $20 \mathrm{Ma}$ for the Palaeoproterozoic migmatites of Grand Canyon to cool ca. $150{ }^{\circ} \mathrm{C}$ from $>700{ }^{\circ} \mathrm{C}$ to ca. $550^{\circ} \mathrm{C}$ and Oliver et al. (1999) concluded that it took more than $20 \mathrm{Ma}$ for the Halls Creek Orogen migmatites in Western Australia to cool from ca. $800{ }^{\circ} \mathrm{C}$ to $650^{\circ} \mathrm{C}$. Although the LGB stayed a long time at high temperature, we have not been able to demonstrate any isotope system resetting, excluding the fluid triggered resetting of garnet-wr Sm-Nd system, during the lower and middle crustal residence. Instead the age spectrum recorded by our mineral geochronology seems to reflect crystallization of minerals at different stages of the evolution of the LGB.

The generation of mantle-derived igneous rocks and metamorphic evolution of the LGB is chronologically correlated with the adolescence of the Svecofennian arc complexes. The exhumation of the LGB took place during the time when granulite-grade metamorphism still took place in the Svecofennian orogen (Korsman et al., 1997, 1999; Mouri et al., 1999).

Concerning intercontinental correlation and plate reconstruction, for example to Greenland and Canada, many questions remain open (cf. Hoffmann, 1989; Hall et al., 1995; Wardle et al., 2002a; 2002b). Chronologically, the LGB is correlated with the arc magmatism of the Nagssugtoqidian orogen in Greenland and similar arcs in Canada (Kalsbeek \& Nutman, 1996; Whitehouse et al., 1998; Wardle et al., 2002b). Collision, deformation and metamorphic events in the LGB took place in the beginning of the Svecofennian orogeny and much earlier than the collision events in Greenland and eastern Canadian Shield. Also, because the major provenance is from $-2.2-2.0 \mathrm{Ga}$ acid rocks, which are almost lacking in the North Atlantic realm but much more abundant in western Canadian Shield, South America, Africa and East Asia, and probably also East-European platform, the LGB seems to have more features in common with these areas than eastern Canada and Greenland. For example, the Aldan Shield records 
abundant $1.92 \mathrm{Ga}$ arc magmatism and 1.9 Ga orogenic deformation, which all are features in common with the LGB. In conclusion, neither provenance nor accretion time show evidence for a close correlation of LGB to Greenland and eastern North America at ca. 1.9 Ga. Partially simultaneous arc magmatism in the LGB and Greenland-North America plate at 1.91 Ga may only indicate existence of simultaneous arc magmatism in different hemispheres of the globe.

\section{Acknowledgements}

Martin Whitehouse is greatly acknowledged for all support related to NORDSIM We are grateful to the staff of the isotope laboratory at the Geological Survey of Finland for assistance. Comments by Eero Hanski and Martin Whitehouse for the first version of the manuscript greatly improved the paper. The journal referees, Stephen Daly and an anonymous are acknowledged for valuable comments. Also, financial support by Finnish Cultural Foundation (A. E. Nordenskiöld fund) is greatly acknowledged. The NORDSIM facility is funded by and operated under an agreement with the Joint Nordic research councils, Geological Survey of Finland and the Swedish Museum of Natural History. This paper is NORDSIM publication \#161.

\section{References}

Aleinikoff, J.F., Burton, W.C., Lyttle, P.J., Nelson, A.E. \& Southworth, C.S., 2000. U-Pb geochronology of zircon \& monazite from Mesoproterozoic granitic gneisses of the northern Blue Ridge, Virginia and Maryland, USA. Precambrian Research 99, 113-146.

Barbey, P. \& Raith, M., 1990. The granulite belt of Lapland. In: Vielzeuf, D. \& Vidal, Ph. (eds.) Granulites and crustal evolution. Kluwer Academic Publishers, Dortrecht, p. 111-132.

Barbey, P., Bernard-Griffiths, J. \& Convert, J., 1986. The Lapland charnockitic complex: REE geochemistry and petrogenesis. Lithos 19, 95-111.

Bernard-Griffiths, J., Peucat, J.J., Postaire, B., Vidal, P., Convert, J. \& Moreau, B., 1984. Isotopic data (U-Pb, $\mathrm{Rb}-\mathrm{Sr}, \mathrm{Pb}-\mathrm{Pb}$ and $\mathrm{Sm}-\mathrm{Nd}$ ) of the mafic granulites from Finnish Lapland. Precambrian Research 23, 325-348.

Bibikova, E.V., Mel’nikov, V.F. \& Avakyan, K.Kh., 1993. Lapland granulites: Petrology, geochemistry, isotopic age. Petrology 1, 181-198.

Bodorkos, S., Cawood, P.A., Olive, N.H.S. \& Nemchin, A.A., 2000. Rapidity of orogenesis in the Palaeoproterozoic Halls Creek Orogen, northern Australia: evi- dence from SHRIMP zircon data, CL zircon images, and mixture modelling studies. American Journal of Science 300, 60-82.

Bostock, H.H., \& van Breemen, O., 1994. Ages of detrital and metamorphic zircons and monazites from a preTaltson magmatic zone basin at the western margin of Rae Province. Canadian Journal of Earth Sciences 31, 1353-1364.

Bowring, S.A. \& Podosek, F.A., 1989. Nd isotopic evidence from Wopmay Orogen for 2.0-2.4 Ga crust in western North America. Earth and Planetary Science Letters 94, 217-230.

Bowring, S.A. \& Grotzinger, J.P., 1992. Implications of new chronostratigraphy for tectonic evolution of Wopmay orogen, northwest Canadian Shield. American Journal of Science 292, 1-20.

Braathen, A. \& Davidsen, B., 2000. Structure and stratigraphy of the Palaeoproterozoic Karasjok Greenstone Belt, North Norway - regional implications. Norsk Geologisk Tidsskrift 80, 33-50.

Bridgwater, D., Austrheim, H., Hansen, B.T., Mengel, F., Pedersen, S. \& Winter, J., 1990. The Proterozoic Nagssugtoqidian mobile belt of southeast Greenland: A link between the eastern Canadian and Baltic shields. Geoscience Canada 17, 305-310.

Bridgwater, D., Campbell, L., Mengel, F., Marker, M. \& Scott, D., 1996. The Nagssugtoqidian of West Greenland in the light of comparative studies of juvenile components in the Palaeoproterozoic Torngat, SE Greenland Nagssugtoqidian, and Lapland-Kola "collisional" belts. $2^{\text {nd }}$ DLC Workshop on Nagssugtoqidian geology, Copenhagen, April 18-19, 1996, Proceedings, p. 8-19.

Bruguier, O., Bosch, D., Pidgeon, R.T., Byrne, D.I. \& Harris, L.B., 1999. U-Pb chronology of the Northampton Complex, Western Australia - evidence for Grenvillian sedimentation, metamorphism and deformation and geodynamic implication. Contributions to Mineralogy and Petrology 136, 258-272.

Buick, I.S., Frei, R. \& Cartwright, I., 1999. The timing of high-temperature retrogression in the Reynolds Range, central Australia: constrains from garnet and epidote $\mathrm{Pb}$ $\mathrm{Pb}$ dating. Contributions to Mineralogy and Petrology $135,244-254$.

Burton, K.W., Kohn, M.J., Cohen, A.S. \& O’Nions, R.K., 1995. The relative diffusivites of $\mathrm{Pb}, \mathrm{Nd}, \mathrm{Sr}$ and $\mathrm{O}$ in garnet. Earth and Planetery Science Letters 133, 199-211.

Chen, C.-H., Nakada, S., Shieh, Y.-N. \& DePaolo, D.J., 1999. The Sr, Nd andO isotopic studies of the 19911995 eruption at Unzen, Japan. Journal of Volcanology and Geothermal Research 89, 243-253.

Chen, F., Hegner, E. \& Todt, W., 2000. Zircon ages and $\mathrm{Nd}$ isotopic and chemical composition of orthogneisses from the Black Forest, Germany: evidence for a Cambrian magmatic arc. International Journal of Earth Sciences $88,791-802$. 
Cheong, H.-S., Kwon, S.-T. \& Park, K.-H., 2000. Pb and $\mathrm{Nd}$ isotopic constraints on the Palaeoproterozoic crustal evolution of the northeastern Yeongnam massif, South Korea. Precambrian Research 102, 207-220.

Claesson, S. \& Lundqvist, T., 1995. Origins and ages of Proterozoic granitoids in the Bothnian Basin, central Sweden; isotopic and geochemical constraints. Lithos $36,115-140$.

Claesson, S., Huhma, H., Kinny, P.D. \& Williams, I.S., 1993. Svecofennian detrital zircon ages - implications for the Precambrian evolution of the Baltic Shield. Precambrian Research 64, 109-130.

Claesson, S., Bogdanova, S.V., Bibikova, E.V. and Gorbatschev, R., 2001. Isotopic evidence for Palaeoproterozoic accretion in the basement of the East European Craton. Tectonophysics 339, 1-18.

Connelly, J.N. \& Mengel, F.C., 2000. Evolution of Archaean components in the Palaeoproterozoic Nagssugtoqidian orogen, West Greenland. Bulletin of the Geological Society of America 112, 747-763.

Connelly, J.N., van Gool, J.A.M. \& Mengel, F.C., 2000. Temporal evolution of deeply eroded orogen: the Nagssugtoqidian orogen. Canadian Journal of Earth Sciences 37, 1121-1142.

Crowley, J.L. \& Parrish, R.R., 1999. U-Pb isotopic constraints on diachronous metamorphism in the northern Monashee complex, southern Canadian Cordillera. Journal of Metamorphic Geology 17, 483-502.

Dada, S.S., 1988. Crust-forming ages and Proterozoic custal evolution in Nigeria: a reappraisal of current interpretations. Precambrian Research 87, 65-74.

Daly, J.S., Balagansky, V.V., Timmerman, M.J. Whitehouse, M.J., de Jong, K., Guise, P, Bogdanova, S., Gorbatschev, R. \& Bridgwater, D., 2001. Ion microprobe U-Pb zircon geochronology and isotopic evidence for a trans-crustal suture in the Lapland-Kola Orogen, northern Fennoscandian Shield. Precambrian Research 105, 289-314.

Daniel, C.G., Hollister, L.S., Parrish, R.R. \& Gruijic, D., 2003. Exhumation of the Main Central Thrust from the lower crustal depths, Eastern Bhutan Himalaya. Journal of Metamorphic Geology 21, 317-334.

DePaolo, D.J., 1981. Neodymium isotopes in the Colorado Front Range and crust-mantle evolution in the Proterozoic. Nature 291, 684-687.

De Wolf, C.P., Zeissler, C.J., Halliday, A.N., Mezger, K. \& Essene, E.J.,, 1996.. The role of inclusions in U-Pb and Sm-Nd garnet geochronology: Stepwise dissolution experiments and trace uranium mapping by fission track analysis. Geochimica Cosmochimica Acta 60, 121-134.

Eskola, P., 1952. On the granulites of Lapland. American Journal of Science, Bowen volume 1, 133-171.

Feybesse, J.L., Johan, V., Triboulet, C., Guerrot, C., Mayaga_Mikolo, F., Bouchot, V. \& Eko N'dong, J., 1998. The West Central African belt: a model of 2.5-2.0 Ga accretion and two phase orogenic evolution. Precambri- an Research 87, 161-216.

Foster, G., Kinny, P., Vance, D., Prince, C. \& Harris, N., 2000. The significance of monazite $\mathrm{U}-\mathrm{Th}-\mathrm{Pb}$ age data in metamorphic assemblages; a combined study of monazite and garnet chronometry. Earth and Planetary Science Letters 181, 327-340.

Friedl, G., Finger, F., McNaughton, N.J. \& Fletcher, I.R., 2000. Deducing the ancestry of terranes: SHRIMP evidence for South America-derived Gondwana fragments in central Europe. Geology 28, 1035-1038.

Friend, C.R.L. \& Kinny, P.D., 2001. A reappraisal of the Lewisian gneiss complex: geochronological evidence for its tectonic assembly from disparate terranes in the Proterozoic. Contributions to Mineralogy and Petrology 142, 198-218.

Frost, B.R., Avchenco, O.V., Chamberlain, K.R. \& Frost, C.D., 1998. Evidence for extensive Proterozoic remobilization of the Aldan shield and implications for Proterozoic plate tectonic reconstruction of Siberia and Laurentia. Precambrian Research 89, 1-23.

Gaál, G. \& Gorbatschev, R., 1987. An outline of the Precambrian evolution of the Baltic Shield. Precambrian Research 35, 15-52.

Gebauer, D. \& Grünenfelder, M., 1976. U-Pb zircon and $\mathrm{Rb}-\mathrm{Sr}$ whole rock dating of low grade metasediments Example: Montagne Noire (southern France). Contributions to Mineralogy and Petrology 59, 13-32.

Hall, J., Wardle, R.J., Gower, C.F., Kerr, A., Coflin, K., Keen, C.E. \& Carrol, P., 1995. Proterozoic orogens of the northeastern Canadian Shield: new information from the Lithoprobe ESCOOT crustal reflection seismic survey. Canadian Journal of Earth Sciences 32, 1119-1131.

Hanski, E., 2001. History of stratigraphic research in Northern Finland. In: Vaasjoki, M. (ed) Radiometric age determinations from Finnish Lapland and their bearing on the timing of Precambrian volcano-sedimentary sequences. Geological Survey of Finland, Special Paper 33, 15-43.

Hanski, E., Vaasjoki, M. \& Huhma, H., 2001. Geochronology of Northern Finland: a summary and discussion. In: Vaasjoki, M. (ed) Radiometric age determinations from Finnish Lapland and their bearing on the timing of Precambrian volcano-sedimentary sequences. Geological Survey of Finland, Special Paper 33, 255-279.

Hanski, E., Huhma, H. \& Perttunen, V., 2005. SIMS U$\mathrm{Pb}, \mathrm{Sm}-\mathrm{Nd}$ isotope and geochemical study of an arkositeamphibolite suite, Peräpohja Schist Belt: evidence for ca. $1.98 \mathrm{Ga}$ A-type felsic magmatism in northern Finland. Bulletin of the Geological Society of Finland 77, 5-29.

Harris, N.B.W., Caddick, M., Korler, J., Goswami, S., Vance, D. \& Tindle, A.G., 2004. The pressure-temperature-time path of migmatites from the Sikkim Himalaya. Journal of Metamorphic Geology, 22, 249-264.

Hartmann, L.A., Leite, J.A.D., McNaughton, N.J. \& Santos, J.O.S., 1999. Deepest exposed crust of Brazil-SHRIMP establishes three events. Geology 27, 947-950.

Hawkins, D.P. \& Bowring, S.A., 1999. U-Pb monazite, 
xenotime and titanite geochronological constraints on the prograde to post-peak metamorphic thermal history of Paleoproterozoic migmatites from the Grand Canyon, Arizona. Contributions to Mineralogy and Petrology $134,150-169$.

Hoffman, P.F., 1988. United plates of America, the birth of a craton: Early Proterozoic assembly and growth of Laurentia. Annual Reviews of Earth and Planetary Sciences 16, 543-603.

Hoffman, P.F., 1989. Precambrian geology and tectonic history of North America. In: Bally, A.W. \& Palmer, A.R. (eds.) The Geology of North America-An Overview. Geological Society of America, Boulder, Colorado, 447-512.

Holtz, F., Johannes, W., Tamic, N. \& Behrens, H., 2001. Maximum and minimum water contents of granitic melts generated in the crust: a reevaluation and implications. Lithos 56, 1-14.

Hörmann, P.K., Raith, M., Raase, P., Ackermand, D. \& Seifert, F., 1980. The granulite complex of Finnish Lapland: petrology and metamorphic conditions in the Ivalojoki-Inarijärvi area. Geological Survey of Finland, Bulletin 308, $100 \mathrm{p}$.

Hsü, K.J., 1989. Time and place in Alpine tectonics-the Fermor lecture. In: Coward, M.P., Dietrich, D. \& Park, R.G. (eds) Alpine Tectonics. Geological Society of London, Special Publicatin, 45, 421-443.

Huhma, H., 1986. Sm-Nd, U-Pb and Pb-Pb isotopic evidence for the origin of the Early Proterozoic Svecokarelian crust in Finland. Geological Survey of Finland, Bulletin 337, $48 \mathrm{p}$.

Huhma, H., 1987. Provenance of early Proterozoic and Archean metasediments in Finland: A Sm-Nd study. Precambrian Research 35, 127-144.

Huhma, H. \& Meriläinen, K., 1991. Provenance of paragneisses from the Lapland granulite belt. In Tuisku, P. \& Laajoki, K. (eds.) Metamorphism, deformation and structure of the crust, abstracts (IGCP 275). Res Terrae, Series A, No.5, p. 26.

Huhma, H., Claesson, S., Kinny, P. \& Williams, I., 1991. The growth of early Proterozoic crust: new evidence from Svecofennian detrital zircons. Terra Nova 3, 175-179.

John, T., Klemd, R., Hirdes, W. \& Loh, G., 1999. The metamorphic evolution of the Palaeoproterozoic (Birimian) volcanic Ashanti belt (Ghana, West Africa). Precambrian Research 98, 11-30.

Jung, S. \& Mezger, K., 2001. Geochronology of migmatites - a Sm-Nd, U-Pb and Rb-Sr study from the Proterozoic Damara belt (Namibia): implications for polyphase development of migmatites in high-grade terranes. Journal of Metamorphic Geology 19, 77-97.

Kalsbeek, F. \& Nutman, A.P., 1996. Anatomy of the Early Proterozoic Nagssugtoqidian orogen, West Greenland, explored by reconnaissance SHRIMP U-Pb zircon dating. Geology 24, 515-518.

Kalsbeek, F., Pidgeon, R.T. \& Taylor, P.N., 1987. Nagssug- toqidian mobile belt of West Greenland: a cryptic 1850 Ma suture between two Archaean continents - chemical and isotopic evidence. Earth and Planetary Science Letters 85, 365-385.

Kalsbeek, F., Nutman, A.P., Escher, J.C., Friderichsen, J.D., Hull, J.M., Jones, K.A. \& Pedersen, S.A.S., 1999. Geochonology of granitic and supracrustal rocks from the northern part of the East Greenland Caledonides: ion microprobe $\mathrm{U}-\mathrm{Pb}$ zircon ages. Geology of Greenland Survey Bulletin 184, 31-48.

Keay, S., Steele, D. \& Compston, W., 1999. Identifying granite sources by SHRIMP U-Pb geochronology: an application to the Lachan foldbelt. Contributions to Mineralogy and Petrology 137, 323-341.

Kesola, R., 1995. Näätämö. Explanation to the Geological map of Finland 1:100 000, pre-Quarternary rocks, sheets 3934+4912+4914 (in Finnish with English summary). Geological Survey of Finland, 88 p.

Korja, T., Tuisku, P., Pernu, T. \& Karhu, J., 1996. Field, petrophysical and carbon isotope studies on the Lapland Granulite Belt: implications for deep continental crust. Terra Nova 8, 48-58.

Korsman, K., Koistinen, T., Kohonen, J., Wennerström, M., Ekdahl, E., Honkamo, M. Idman, H. \& Pekkala, Y. (eds) 1997. Suomen kallioperäkartta/Bedrock map of Finland, 1:1 000 000. Geological Survey of Finland, Espoo.

Korsman, K., Korja, T., Pajunen, M., Virransalo, P. \& GGT/SVEKA Working Group, 1999.. The GGT/SVEKA transect : structure and evolution of the continental crust in the Paleoproterozoic Svecofennian orogen in Finland. International Geology Review 41, 287-333.

Krogh, T., 1973. A low-contamination method for hydrothermal decomposition of zircon and extraction of $U$ and $\mathrm{Pb}$ for isotopic age determinations. Geochimica et Cosmochimica Acta 37, 485-494.

Kröner, A., Puustinen, K. \& Hickman, M., 1981. Goechronology of an Archaean tonalitic gneiss dome in northern Finland andits relation with an unusual overlying volcanic conglomerate and komatiitic greenstone. Contributions to Mineralogy and Petrology 76, 33-41.

Lahtinen, R., Huhma, H. \& Kousa, J., 2002. Contrasting source components of the Paleoproterozoic Svecofennian metasediments: Detrital zircon U-Pb, Sm-Nd and geochemical data. Precambrian Research 116, 81-109.

Lee, S.R., Cho, M., Yi, K. \& Stern, R.A., 2000. Early Proterozoic granulites in central Korea, tectonic correlation with Chinese cratons. Journal of Geology 108, 729-738.

Leibinger, S., 1996. The North-Eastern Marginal Zone of the Lapland Granulite Belt at Kaamanen (Northern Finland): Lithology and Tectono-Metamorphic Development. Unpublished Graduate Thesis, Johann-WolfgangGoethe-Universität, Frankfurt, 95 p.

Ludwig, K.R.,, 1991. PbDat 1.21 for MS-dos: A computer program for processing $\mathrm{Pb}-\mathrm{U}-\mathrm{Th}$ isotope data. Version 1.08. U.S. Geological Survey Open-File Report 
$88-542,35 \mathrm{p}$.

Ludwig, K.R., 2001. Isoplot/Ex rev. 2.49. A Geochronological Toolkit for Microsoft Excel. Berkeley Geochronologicy Center, Special Publication No. 1a, 55 p.

Manninen, T., Pihlaja, P. \& Huhma, H.,, 2001. U-Pb geochronology of the Peurasuvanto area, northern Finland. In: Vaasjoki, M. (ed.) Radiometric age determinations from Finnish Lapland and their bearing on the timing of Precambrian volcano-sedimentary sequences. Geological Survey of Finland, Special Paper 33, 189-200.

Mapeo, R.B.M., Armstrong, R.A. \& Kampunzu, A.B., 2001. SHRIMP U-Pb zircon geochronology of gneisses from the Gweta borehole, northeast Botswana: implications for the Palaeoproterozoic Magondi Belt in southern Africa. Geological Magazine 138, 299-308.

Marker, M., 1988. Early Proterozoic thrusting of the Lapland Granulite Belt and its geotectonic evolution, northern Baltic Shield. Geologiska Föreningens i Stockholm Förhandlingar 110, 405-410.

Meriläinen, K., 1976. The granulite complex and adjacent rocks in Lapland, northern Finland. Bulletin of the Geological Survey of Finland 281, 1-129.

Mezger, K. \& Krogstad, E.J., 1997. Interpretation of discordant $\mathrm{U}-\mathrm{Pb}$ zircon ages - an evaluation. Journal of Metamorphic Geology 15, 127-140.

Mezger, K., Essene, E.J. \& Halliday, A.N., 1992. Closure temperatures of the Sm-Nd system in metamorphic garnets. Earth and Planetery Science Letters 113, 397-409.

Mouri, H., Korsman, K. \& Huhma, H., 1999. Tectonometamorphic evolution and timing of the melting prosesses in the Svecofennian Tonalite-Trondhjemite Migmatite Belt: An example from Luopioinen, Tampere area, southern Finland. Bulletin of the Geological Society of Finland 71, 31-56.

Murphy, J.B. \& Hamilton, M.A., 2000. Orogenesis and basin development: $\mathrm{U}-\mathrm{Pb}$ detrital zircon age constraints on the evolution of the late Palaeozoic St. Marys Basin, central Mainland, Nova Scotia. Journal of Geology $108,53-71$.

Nomade, S., Féraud, G., Chen, Y. \& Pouclet, A., 2002. Thermal and tectonic evolution of the Palaeoproterozoic Transamzonian orogen as deduced from ${ }^{40} \mathrm{Ar} /{ }^{39} \mathrm{Ar}$ and AMS along the Oyapok river (French Guyana). Precambrian Research 114, 35-53.

Norcross, C., Davis, D.W., Spooner, E.T.C. \& Rust, A., 2000. U-Pb and $\mathrm{Pb}-\mathrm{Pb}$ age constraints on Palaeoproterozoic magmatism, deformation and gold mineralization in the Omai area, Guyana Shield. Precambrian Research 102, 69-86.

Nutman, A.P., Bennet, V.C., Friend, C.R.L. \& Norman, M.D., 1999. Meta-igneous (non-gneissic) tonalites and quartz-diorites from an extensive ca. $3800 \mathrm{Ma}$ terrain south of the Isua supracrustal belt, southern West Greenland: constraints on early crust deformation. Contributions to Mineralogy and Petrology 137, 364-388.
Oliver, N.H.S., Bodorkos, S., Nemchin, A.A., Kinny, P.D. \& Watt, G.R., 1999. Relationship between zircon U-Pb SHRIMP ages and leucosome type in migmatites of the Halls Creek Orogen, Western Australia. Journal of Petrology 40, 1553-1575.

Parrish, R.R. \& Whitehouse, M.J., 1999. Constraints on the diffusivity of $\mathrm{Pb}$ in Monazite, its closure temperature, and its U-Th-Pb systematics in metamorphic terrains, from a TIMS and SIMS study. Journal of Conference Abstracts 4, p. 711.

Peltonen, P., Kontinen, A. \& Huhma, H., 1998. Petrogenesis of the mantle sequence of the Jormua Ophiolite (Finland): melt migration in the upper mantle during Palaeoproterozoic continental break-up. Journal of Petrology 39, 297-329.

Perchuk, L.L., Gerya, T.V., van Reenen, D.D., Krotov, A.V., Safonov, O.G., Smit, C.A. \& Shur, M.Yu., 2000. Comparative petrology and metamorphic evolution of the Limpopo (South Africa) and Lapland (Fennoscandia) high grade terrains. Mineralogy and Petrology 69, 69-107.

Pidgeon, R.T. \& Aftalion, M., 1972. The geochronological significance of discordant $\mathrm{U}-\mathrm{Pb}$ ages of oval shaped zircons from a Lewisian gneiss from Harris, Outer Hebrides. Earth and Planetary Science Letters 17, 269-274.

Pidgeon, R.T., O’Neil, J.R. \& Silver, L.T., 1966. Uranium and lead isotopic stability in a metamict zircon under experimental hydrothermal conditions. Science 154, $1538-1540$.

Plá Cid, J., Bitencourt, M.F., Nardi, L.V.S., Conceicão, H., Bonin, B. \& Lafon, J.M., 2000. Palaeoproterozoic lateorogenic alkaline granitic magmatism from northeast Brazil. Precambrian Research 104, 47-75.

Plint H.E. \& McDonough, M.R., 1995. ${ }^{40} \mathrm{Ar} /{ }^{39} \mathrm{Ar}$ and K-Ar age constraints on shear zone evolution, southern Taltson magmatic zone, northeastern Alberta. Canadian Journal of Earth Science 32, 281-291.

Raith, M. \& Raase, P., 1986. High grade metamorphism in the granulite belt of Finnish Lapland. In: Dawson, J.B., Carswell, D.A., Hall, J. \& Wedepohl, K.H. (eds.) The Nature of the Lower Continental Crust. Geological Society of London, Special Publication No 24, 283-295.

Rastas, P., Huhma, H., Hanski, E., Lehtonen, M.I., Paakkola, J., Mänttäri, I. \& Härkönen, I,, 2001. U-Pb isotopic studies on the Kittilä greenstone area, central Lapland, Finland. In: Vaasjoki, M. (ed.) Radiometric age determinations from Finnish Lapland and their bearing on the timing of Precambrian volcano-sedimentary sequences. Geological Survey of Finland, Special Paper 33, 95-141.

Romer, R. \& Öhlander, B., 1995. Tectonic implications of an $1846 \pm 1$ Ma old migmatitic granite in south-central Sweden. Geologiska Föreningens i Stockholm Förhandlingar 117, 69-74

Ross, G.M., Milkereit, E., Eaton, D., White, D., Kanasewich, E.R. \& Burianyk, M.J.A., 1995. Palaeoproterozo- 
ic collisional orogen beneath the Western Canada sedimentary basin imaged by Lithoprobe crustal seismic-reflection data. Geology 23, 195-199.

Rutland, R.W.R., Williams, I.S. and Korsman, K., 2004. Pre-1.91 Ga deformation and metamorphism in the Palaeoproterozoic Vammala Migmatite Belt, southern Finland, and implications for Svecofennian tectonics. Bulletin of the Geological Society of Finland 76, 93-140.

Schaltegger, U., Fanning, C.M., Günther, D., Maurin, J.C., Schulmann, K. \& Gebauer, D., 1999. Growth, annealing and recrystallization of zircon and preservation of monazite in high-grade metamorphism: conventional and in-situ U-Pb isotope, cathodoluminescence and microchemical evidence. Contributions to Mineralogy and Petrology 134, 186-201.

Scott, D.J., Stern, R.A., St.Onge, M.R. \& McMullen, S.M., 2002. U-Pb geochronology of detrital zircons in the metasedimentary rocks from southern Baffin island: implications for the Palaeoproterozoic tectonic evolution of Northeastern Laurentia. Canadian Journal of Earth Sciences 39, 611-623.

Searle, M.P. \& Godin, L., 2003. The South Tibetan Detachment and the Manaslu leucogranite: A structural reinterpretation and restoration of the Annapurna-Manaslu Himalaya, Nepal. Journal of Geology, 111, 505-523.

Seipold, U., Mueller, H.-J. \& Tuisku, P., 1998. Principle differences in the pressure dependence of thermal and elastic properties of crystalline rocks. Physics and Chemistry of the Earth 23, 357-360.

Sinha, A.K., Wayne, D.M. \& Hewitt, D.A., 1992. The hydrothermal stability of zircon - preliminary experimental and isotopic studies. Geochimica et Cosmochimica Acta 56, 3551-3560.

Sircombe, K.N., 2000. Quantitative comparison of large sets of geochronological data using multivariate analysis: A provenance study example from Australia. Geochimica et Cosmochimica Acta 64, 1593-1616.

Söllner, F., Miller, H. \& Höll, R., 1997. Alter und Genese rhyodazitischer Metavulkanite ("Porphyroide") der Nördlichen Grauwackenzone und der Karnischen Alpen (Österreich): Ergebnissa von U-Pb-Zirkondatierungen. Zeitschrift der deutschen geologischen Gesellschaft 148, 499-522.

Sorjonen-Ward, P., Claoué-Long J. \& Huhma H., 1994. SHRIMP isotope studies of granulite zircons and their relevance to early Proterozoic tectonics in northern Fennoscandia. U.S.G.S. Circular 1107, p. 299.

Spear, F.S. \& Parrish, R., 1996. Petrology and cooling rates of the Valhalla Complex, British Columbia, Canada. Journal of Petrology 37, 733-765.

Stacey, J.S. \& Kramers, J.D., 1975. Approximation of terrestial lead isotope evolution by a two-stage modell. Earth and Planetary Science Letters 26, 207-221.

Sturt, B.A., Melezhik, V.A. \& Ramsay, D.M., 1994. Early Proterozoic regolith at Pasvik, NE Norway: palaeoenvironmental implications for the Baltic Shield. Terra No- va 6, 618-633.

Sun, S.-s. \& McDonough, W.F., 1989. Chemical and isotopic systems of oceanic basalts: implications for the mantle composition and processes. In: Saunders, A.D. \& Norry, M.J. (eds) Magmatism in the Ocean Basins, Geological Society Special Publication 42, 313-345.

Thöni, M., 2003. Sm-Nd isotope systematics in garnet from different lithologies (Eastern Alps): age results, and an evolution of potential problems for garnet $\mathrm{Sm}-\mathrm{Nd}$ chronometry. Erratum. Chemical Geology 194, 353-379.

Tuisku, P. \& Huhma, H., 1998. Eclogite from the marginal zone of the Lapland granulite belt: evidence from the 1.90-1.88 Ga subduction zone. Geological Survey of Finland, Special Paper 26, p. 61.

Tuisku, P. \& Huhma, H., 1999. SIMS U-Pb dating of zircons from migmatite khondalites and enderbite from Lapland granulite belt, Finland. Terra Abstracts 11, 710-711.

Tuisku, P. \& Makkonen, H.V., 1999. Spinel-bearing symplectites in Palaeoproterozoic ultramafic rocks from two different geological settings in Finland: thermobarometric and tectonic implications. Geologiska Föreningens i Stockholm Förhandlingar 121, 293-300.

Tuisku, P., Mikkola, P. \& Huhma, H., 2006. Evolution of Migmatitic Granulite Complexes: Implications from Lapland Granulite Belt, Part I: Metamorphic geology. Bulletin of the Geological Society of Finland 78, 71-105.

Vaasjoki, M., (ed.), 2001. Radiometric age determinations from Finnish Lapland and their bearing on the timing of Precambrian volcano-sedimentary sequences. Geological Survey of Finland, Special Paper 33, 279 p.

Vaasjoki, M., Huhma, H., Lahtinen, R. \& Vestin, J., 2003. Sources of Svecofennian granitoids in the light of ion probe U-Pb measurements on their zircons. Precambrian Research 121, 251-262.

Vanderhaeghe, O., Teyssier, C. \& Wysoczanski, R., 1999. Structural and geochronological constraints on the role of partial melting during the formation of the Shuswap metamorphic core complex at the latitude of the ThorOdin dome, British Columbia. Canadian Journal of Earth Sciences 36, 917-943.

Vavra, G. \& Schaltegger, U., 1999. Post granulite facies monazite growth and rejuvenation during Permian to Lower Jurassic thermal and fluid events in the Ivrea Zone (Southern Alps). Contributions to Mineralogy and Petrology 134, 405-414.

Vavra, G., Schmid, R. \& Gebauer, D., 1999. Internal morphology, habit and U-Th-Pb microanalysis of amphibolite-to-granulite facies zircons: geochronology of the Ivrea Zone (Southern Alps). Contributions to Mineralogy and Petrology 134, 380-404.

Villa, I., 1998. Isotopic closure. Terra Nova 10, 42-47.

Wallis, S, Banno, S. \& Komatsu, M. (eds.), 1998. Mid to deep crustal processes in the island arc setting: the metamorphic belts of Japan. Journal of Metamorphic Geology $16,1-140$. 
Wardle, R.J., James, D.T., Scott, D.J. \& Hall, J., 2002a. The southeastern Churchill Province: Synthesis of a Palaeoproterozoic transpressional orogen. Canadian Journal of Earth Sciences 39, 639-663.

Wardle, R.J., Gower, C.F., James, D.T., St-Onge, M., Scott, D.J., Garde, A.A., Culshaw, N.G., van Gool, J.A.M., Connelly, J.A., Perreault, S. \& Hall, J., 2002b. Correlation Chart of the Proterozoic assembly of the northeastern Canadian - Greenland Shield. Canadian Journal of Earth Sciences 39, Chart 1.

White, R.W., Clarke, G.L. \& Nelson, D.R., 1999. SHRIMP $\mathrm{U}-\mathrm{Pb}$ zircon dating of Grenville-age events in the western part of the Musgrave Block, central Australia. Journal of Metamorphic Geology 17, 465-481

Whitehouse, M.J. \& Platt, J.P., 2003. Dating high-grade metamorphism-constraints from rare-earth elements in zircon and garnet. Contributions to Mineralogy and Petrology 145, 61-74.

Whitehouse, M.J., Claesson, S., Sunde, T. \& Vestin, J., 1997. Ion-microprobe U-Pb zircon geochronology and correlation of Archaean gneisses from the Lewisian Complex of Gruinard Bay, north-west Scotland. Geochimica et Cosmochimica Acta 61, 4429-4438.

Whitehouse, M.J., Kalsbeek, F. \& Nutman, A.P., 1998. Crustal growth and crustal recycling in the Nagssugtoqidian orogen of West Greenland: Constraint from radiogenic isotope systematics and $\mathrm{U}-\mathrm{Pb}$ zircon geochronology. Precambrian Research 91, 365-381.

Whitehouse, M.J., Kamber, B.S. \& Moorbath, S., 1999. Age significance of the early Archaean rocks of west Greenland-a reassessment based on combined ion-microprobe and imaging studies. Chemical Geology 160, 201-224.

Wiedenbeck, M., Allé, P., Corfu, F., Griffin, W.L., Meier, M., Oberli, F., von Quadt, A., Roddick, J.C. \& Spiegel, W., 1995. Three natural zircon standards for U-Th-Pb, Lu-Hf, trace element and REE analysis. Geostandards Newsletter 19, 1-12.

Williams, I.S., 1992. Some observations on the use of zircon $\mathrm{U}-\mathrm{Pb}$ geochronology in the study of granitic rocks. Transactions of the Royal Society of Edinburgh: Earth Sciences 83, 447-458.

Williams, I.S., Buick, I.S. \& Cartwright, I., 1996. An extended episode of early Mesoproterozoic metamorphic fluid flow in the Reynolds Range, central Australia. Journal of Metamorphic Geology 14, 29-47.

Zhao, G., Cawood, P.A., Wilde, S.A., Sun. M. \& Lu, L., 2000. Metamorphism of basement rocks in the Central Zone of the North China Craton: implications for Palaeoproterozoic tectonic evolution. Precambrian Research $103,55-88$. 